\title{
Deep-water Ophiuroidea (Echinodermata) from off Chile in the Eastern South Pacific
}

\author{
Cynthia Lara de Castro Manso ${ }^{1,2}$ \\ ${ }^{1}$ Laboratório de Invertebrados Marinhos - LABIMAR, Departamento de Biociências, \\ Universidade Federal de Sergipe - UFS, \\ Campus Prof. Alberto Carvalho, Av.Vereador Olímpio Grande, s/n, CEP 49500-000, Itabaiana, SE, Brazil \\ ${ }^{2}$ Corresponding Author: Cynthia Lara de Castro Manso,e-mail: cynthia@phoenix.org.br
}

MANSO, C.L.C. Deep-water Ophiuroidea (Echinodermata) from off Chile in the Eastern South Pacific. Biota Neotrop. 10(2): http://www.biotaneotropica.org.br/v10n2/en/abstract?inventory+bn00810022010.

\begin{abstract}
The ophiuroids collected during the Oceanographic Expedition PUCK (SONNE-156) in 2001, in the framework of the project "Interactions between productivity and environment along the Chilean continental shelf" were analyzed. Eight samples had ophiuroids; Fifteen species were distributed in the following families: Gorgonocephalidae (2), Asteronychidae (2), Ophiomyxidae (1), Ophiacanthidae (2), Ophiuridae (5), Amphiuridae (1), and Ophiolepididae (2). Four species were recorded for the first time from Chilean waters, i.e., Asteronyx loveni Müller \& Troschel, Astrodia tenuispina Verrill, Ophiolimna bairdi (Lyman), and Ophiocten amitinum Lyman, and three are new, i.e., Ophiura (Ophiuroglypha) arntzi sp. nov., Amphiophiura gallardoi sp. nov., and Stegophiura wilhelmi sp. nov.

Keywords: ophiuroid, deep-water, Chilean continental margin, Chilean abyssal zone, taxonomic diversity.
\end{abstract}

MANSO, C.L.C. Ophiuroidea (Echinodermata) de aguas profundas del Pacifico Sur-Oriental. Biota Neotrop. 10 (2): http://www.biotaneotropica.org.br/v10n2/pt/abstract?inventory+bn00810022010.

Resumen: Se analizan los ofiuroídeos colectados durante la expedición oceanográfica PUCK (SONNE-156) en 2001, en el marco del proyecto "Interacciones entre la productividad y el ambiente a lo largo de la plataforma continental chilena". Ocho muestras con ofiuroídeos contenían un total de 15 especies: Gorgonocephalidae (2), Asteronychidae (2), Ophiomyxidae (1), Ophiacanthidae (2), Ophiuridae (5), Amphiuridae (1), y Ophiolepididae (2). Cuatro especies fueron registradas por primera vez en Chile, i.e., Asteronyx loveni Müller \& Troschel, Astrodia tenuispina Verrill, Ophiolimna bairdi (Lyman), y tres son nuevas especies, i.e., Ophiura (Ophiuroglypha) arntzi sp. nov., Amphiophiura gallardoi sp. nov., and Stegophiura wilhelmi sp. nov.

Palabras-clave: ofiuroideos, aguas profundas, margen continental de Chile, zona abisal de Chile, diversidad taxonómica. 


\section{Introduction}

Among the main studies dealing with Chilean shelf and abyssal echinoderms we note those resulting from expeditions like the "Challenger" (Lyman 1882), revised by Ludwig (1898, 1899); the "Discovery" (Mortensen 1936); the Lund University Chile Expedition (Mortensen 1952); the Mar-Chile Expeditions I and II, the Chiloé I Expedition (Castillo-Alarcón 1968) and the "Eltanin" Expedition, which studied the relationship between the Antarctic and the Eastern South Pacific faunas off Chile and Peru (Tommasi 1976) and Quiroga $\&$ Sellanes (2009) studied the growth and size-structure of the ophiuroid Stegophiura sp. on the continental slope off central Chile. Other papers about Chilean coast dealing with shallower ofiuroids, like Jaramillo (1981) about the ophiuroids from Chiloé \& Conos inlets and Dahm (1999) compared of the shallow water $(<550 \mathrm{~m})$ ophiuroid fauna of the Magellan region and the high-Antarctic Weddell Sea.

In spite of these efforts more recent papers about the ophiuroids of the shelf and slope of Chilean waters are very scarce and only 40 species are registered off Chilean margin.

Here we report on Ophiuroidea (Echinodermata) obtained in the continental margin and bathyal zone off Chile, between $22^{\circ} \mathrm{S}$ and $42^{\circ} \mathrm{S}$ latitude, by the Chilean-German PUCK Expedition (SONNE-156, 2001).

\section{Materials and Methods}

The ophiuroids were collected off Chile with an Agassiz trawl with a mouth width of $1.5 \mathrm{~m}$ and $10 \mathrm{~mm}$ mesh during the PUCK-156 Expedition (2001) onboard R/V Sonne in three areas along Chilean coast at three stations 7103,7105 and 7106 (800 - 1,775 m) off
Antofagasta $\left(22^{\circ} \mathrm{S}\right)$, two stations 7166 and 7167 (1,424 - 2,225 m) off Concepción $\left(36^{\circ} \mathrm{S}\right)$ and three stations 7174,7177 and 7178 $(1,153-507 \mathrm{~m})$ off Chiloé $\left(42^{\circ} \mathrm{S}\right)$ (Table 1$)$. They were washed in filtered seawater, fixed in $10 \%$ formalin with borax and placed after in $70 \%$ ethanol. A detailed description of the sampling procedure has been presented by Arntz et al. (1999). The identification was performed on dried specimens following (Paterson 1985), Stöhr (2005) and O'Hara \& Stöhr (2006). The systematics follows Smith et al. (1995). For the synonyms of the species see Paterson (1985). All specimens were measured and photographed. The disc diameter (dd) was measured from the edge of a inter-radius across the dorsal disc to the edge of the opposite radius (distal edge of the radial shields where present) according to Störh (2005), with a Mitsutoyo caliper. In this work we describe new species and species found for the first time off the Chilean coast. For the species previously found off the Chilean margin and collected again during the PUCK Expedition (i.e., Gorgonocephalus chilensis (Philippi), Astrotoma agassizii Lyman, Ophiomyxa vivipara Studer, Ophiura (Ophiuroglypha) lymani Ljungman, Amphioplus magellanica (Mortensen), Ophiomusium biporicum Castillo-Alárcon and Ophiomusium lymani (Wyville-Thomson) we presented their geographical distribution. The specimens were deposited in the National Museum of the Federal University of the Rio de Janeiro (EqMN), and the Federal University of the Sergipe (UFSITAB), Itabaiana Campus, Brazil.

For the taxonomy of the family Ophiuridae, Paterson's P = L, V formula was adopted. This allows to describe the number of tentacle scales of the arms located around the pores closer to the disc, where A.P. $1=$ the first arm pore, A.P. $2=$ the second arm pore, A.P. $3=$ the

Table 1. List of Ophiuroidea on stations and depth (m) of the collection during the PUCK Expedition (SONNE-156) in 2001 to the Eastern South Pacific margin off Chile.

\begin{tabular}{|c|c|c|c|c|c|c|c|c|}
\hline $\begin{array}{c}\text { Station number } \\
\text { depth }(\mathrm{m})\end{array}$ & $\begin{array}{r}7103 \\
(846) \\
\end{array}$ & $\begin{array}{c}7105 \\
(\mathbf{1 7 7 5}) \\
\end{array}$ & $\begin{array}{c}7106 \\
(1312) \\
\end{array}$ & $\begin{array}{c}7166 \\
(1424) \\
\end{array}$ & $\begin{array}{c}7167 \\
(2225) \\
\end{array}$ & $\begin{array}{c}7174 \\
(1153) \\
\end{array}$ & $\begin{array}{l}7177 \\
(995) \\
\end{array}$ & $\begin{array}{l}7178 \\
(507) \\
\end{array}$ \\
\hline OPHIUROIDEA & - & - & - & - & - & - & - & - \\
\hline Gorgonocephalidae & - & - & - & - & - & - & - & - \\
\hline Gorgonocephalus chilensis & - & - & - & - & - & - & - & 1 \\
\hline Astrotoma agassizii & - & - & - & - & - & - & - & 3 \\
\hline Asteronychidae & - & - & - & - & - & - & - & - \\
\hline Asteronyx loveni & - & - & 1 & 1 & - & - & - & - \\
\hline Astrodia tenuispina & - & - & - & - & - & - & - & 1 \\
\hline Ophiomyxidae & - & - & - & - & - & - & - & - \\
\hline Ophiomyxa vivipara & - & - & - & - & - & - & - & 1 \\
\hline Ophiacanthidae & - & - & - & - & - & - & - & - \\
\hline Ophiacantha sp. & - & - & - & - & - & - & - & 1 \\
\hline Ophiolimna bairdi & - & 1 & - & - & - & - & - & - \\
\hline Ophiuridae & - & - & - & - & - & - & - & - \\
\hline Ophiocten amitinum & - & 14 & - & 11 & 122 & - & - & - \\
\hline Ophiura (Ophiuroglypha) lymani & - & - & - & - & - & - & - & 2 \\
\hline Ophiura (Ophiuroglypha) arntzi sp. nov. & 2 & - & - & - & - & - & - & - \\
\hline Stegophiura wilhelmi sp. nov. & - & - & - & - & - & - & 2 & - \\
\hline Amphiophiura gallardoi sp. nov. & - & - & - & 17 & - & - & - & - \\
\hline Amphiuridae & - & - & - & - & - & - & - & - \\
\hline Amphioplus magellanica & - & 1 & - & - & - & - & - & - \\
\hline Ophiolepididae & - & - & - & - & - & - & - & - \\
\hline Ophiomusium biporicum & - & - & - & - & - & - & - & 5 \\
\hline Ophiomusium lymani & - & - & 8 & - & - & 10 & 1 & - \\
\hline
\end{tabular}


third arm pore, and so on; $\mathrm{L}=$ the number of tentacle scales which arise from the lateral arm plate or from the abradial portion of the pore furthest from the mid-line of the arm; and V = those tentacle scales which arise from the ventral arm plate on the abradial portion of the pore nearest the mid-line of the arm (Paterson 1985).

\section{Results}

Fifteen species of ophiuroids were identified; among these, three species are proposed as new: Ophiura (Ophiuroglypha) arntzi sp. nov., Amphiophiura gallardoi sp. nov., and Stegophiura wilhelmi sp. nov., and four are recorded for the first time in the Eastern South Pacific region: Astrodia tenuispina (Verrill, 1884), Asteronyx loveni Müller \& Troschel, 1842, Ophiolimna bairdi (Lyman, 1883), and Ophiocten amitinum Lyman, 1878. The richest station in species was \# 7178 (off Chiloé) at $507 \mathrm{~m}$ depth with seven species while the deeper stations yielded only 1-2 species each. The most abundant species were Ophiocten amitinum between 1, 424 and 2,225 m depth, followed by Ophiomusium lymani and Amphiophiura gallardoi sp. nov., between 1,000 and 1,424 m depth, while all other species were scarce and occurred as single or few individuals (Table 2). All species occurred at rather narrow depth ranges, usually at a single station or within a few hundred meters.

\section{Systematics}

Class Ophiuroidea Gray, 1840

Sub class Ophiuridea Gray, 1840

Order Euryalida Lamarck, 1816

Family Gorgonocephalidae Ljungman, 1867 (emend. Mortensen, 1933)

Gorgonocephalus chilensis (Philippi, 1858) (Figure 1a-c).

Material examined: Sta. \# 7178, 507 m, UFSITAB-95 (1 specimen).

Distribution: South of the South America from the Atlantic coast $\left(36^{\circ} \mathrm{S}\right.$ Argentina) to the Pacific coast (36 $46^{\circ} \mathrm{S}$ - Canon of Bio-Bio on Chilean coast), and the Juan Fernandez, Malvinas, Georgias del Sur, Kerguelen Islands and New Zealand, Antarctic, Heard and Cabo region (South Africa), with bathymetric range 0-500 m (Jaramillo 1981, Bernasconi \& D’Agostino 1977).

Astrotoma agassizii Lyman, 1875 (Figure 2a, b)

Material examined: Sta.\# 7178,507 m,EqMN3001(2 specimens); UFSITAB-94 (1 specimen).

Distribution: Along the Chilean margin between Chiloe $\left(42^{\circ} \mathrm{S}\right)$ and the Strait of Magellan. On the South Atlantic to North $\left(39^{\circ}\right)$ off Argentina Coast; Tierra del Fuego; Malvinas, Georgias del Sur and Shag Rocks Islands; Antarctic region (Tierra de Graham, Ross Sea, Haakon VII Sea; Tierra Adelia, Reina María, Mac Robertson y Enderby). Bathymetric range 74-1,000 m (Bernasconi \& D’Agostino, 1977).

Family ASTERONYCHIDAE Müller \& Troschel, 1840 (Emend. Mortensen, 1933)

Asteronyx loveni Müller \& Troschel, 1842 (Figure 3a-e)

Material examined: Sta. \# 7106, 1,312 m, EqMN 3007 (1 specimen); Sta. \# 7166, 1,424 m, UFSITAB-86 (1 specimen).

Description: The disc is pentagonal, 14 to $27 \mathrm{~mm}$ in disc diameter, and covered with skin, in which some isolated small
Table 2. Location of the collecting stations.

\begin{tabular}{|c|c|c|c|c|}
\hline Station & $\begin{array}{l}\text { Date } \\
(2001)\end{array}$ & $\begin{array}{c}\text { Latitude } \\
\text { (S) }\end{array}$ & $\begin{array}{l}\text { Longitude } \\
(\mathrm{W})\end{array}$ & $\begin{array}{c}\text { Depth } \\
\text { (m) }\end{array}$ \\
\hline 7103 & 02 April & $22^{\circ} 51^{\prime} 99^{\prime \prime}$ & $70^{\circ} 32^{\prime} 58^{\prime \prime}$ & 846 \\
\hline 7105 & 03 April & $22^{\circ} 48^{\prime} 07^{\prime \prime}$ & $70^{\circ} 42^{\prime} 29^{\prime \prime}$ & 1.775 \\
\hline 7106 & 04 April & $22^{\circ} 48^{\prime} 02^{\prime \prime}$ & $70^{\circ} 36^{\prime} 71^{\prime \prime}$ & 1.312 \\
\hline 7166 & 26 June & $36^{\circ} 27^{\prime} 99^{\prime \prime}$ & $73^{\circ} 46^{\prime} 47^{\prime \prime}$ & 1.424 \\
\hline 7167 & 26 April & $36^{\circ} 27^{\prime} 17^{\prime \prime}$ & $73^{\circ} 54^{\prime} 18^{\prime \prime}$ & 2.225 \\
\hline 7174 & 03 May & $42^{\circ} 32^{\prime} 64^{\prime \prime}$ & $75^{\circ} 00^{\prime} 07^{\prime \prime}$ & 1.153 \\
\hline 7177 & 03 May & $42^{\circ} 34^{\prime} 93^{\prime \prime}$ & $74^{\circ} 50^{\prime} 25^{\prime \prime}$ & 995 \\
\hline 7178 & 03 May & $42^{\circ} 35^{\prime} 35^{\prime \prime}$ & $75^{\circ} 48^{\prime} 35^{\prime \prime}$ & 507 \\
\hline
\end{tabular}

plates are observed. The radial shields are long, bar-shaped and separated, reaching the central region of the disc. These radial shields are actually overlain by several small plates. The ventral inter-radial surface is also covered with skin, in which some round and dispersed scales are observed. The bursal slits are small, about one arm segment long, bordered distally by an immense genital plate and proximally by small genital scales. The jaws and oral area are covered with thick skin. The jaws are elevated proximally, with three or more blunt papillae at the tip and three or four small lateral papillae extending along each side of the jaws. Oral shields are small, with narrower proximal edge and rounded distal edge. Adoral shields are larger and separates the oral shield from the first lateral arm plate. The arms are long, covered with skin, and very coiled, without dorsal plates. The ventral plates are also covered with thick skin. The lateral arm plates bear spines on their ventral part. The first and second segments bear one spine; from the third pore onwards numbers increase up to seven spines in the middle of the arm. These spines adhere to an erect articulation ridge with a round facet for each spine. The arm spines are very small and hook-shaped with several teeth, the ventral one a little larger than the rest on proximal segments, until segment 28, where it becomes extremely big, reaching the opposite lateral plate. This spine is club-shaped, mace-like, with a slightly rugose body and with terminal multiple points. Towards the distal end of the arm these bigger spines become increasingly smaller again, until they are just a little larger than the others.

Distribution: As recorded by Paterson (1985), this species is widely distributed. It has not been recorded in the Arctic Ocean and some parts of the Southern hemisphere. This is the first record for the Eastern South Pacific region off Chile.

Astrodia tenuispina (Verril, 1884) (Figure 4a-d)

Material examined: Sta. \# 7178, 507 m, EqMN 2998 (1 specimen).

Description: The disc is slightly pentagonal, $17 \mathrm{~mm}$ in diameter, covered with a thin skin, in which small round scales can be observed. The bar-shaped radial shields reach the middle of the disc and are separated distally by scales larger than those observed in the interradial areas of the dorsal surface. The ventral surface is covered by small rounded scales, dispersed in the central part and joined and concentrated towards the edges of the disc. The bursal slits are short and located between the first and the second arm segment, bordered by small and rounded genital scales, isolated on its proximal portion, and by an accumulation of scales at the distal edge. The oral shields are extremely small or even absent. The only shield that is distinct is the madreporite, which is triangular and presents two hydropores on its distal part. The adoral shields are long, proximally contiguous, and separate completely the remaining oral shields from the first 

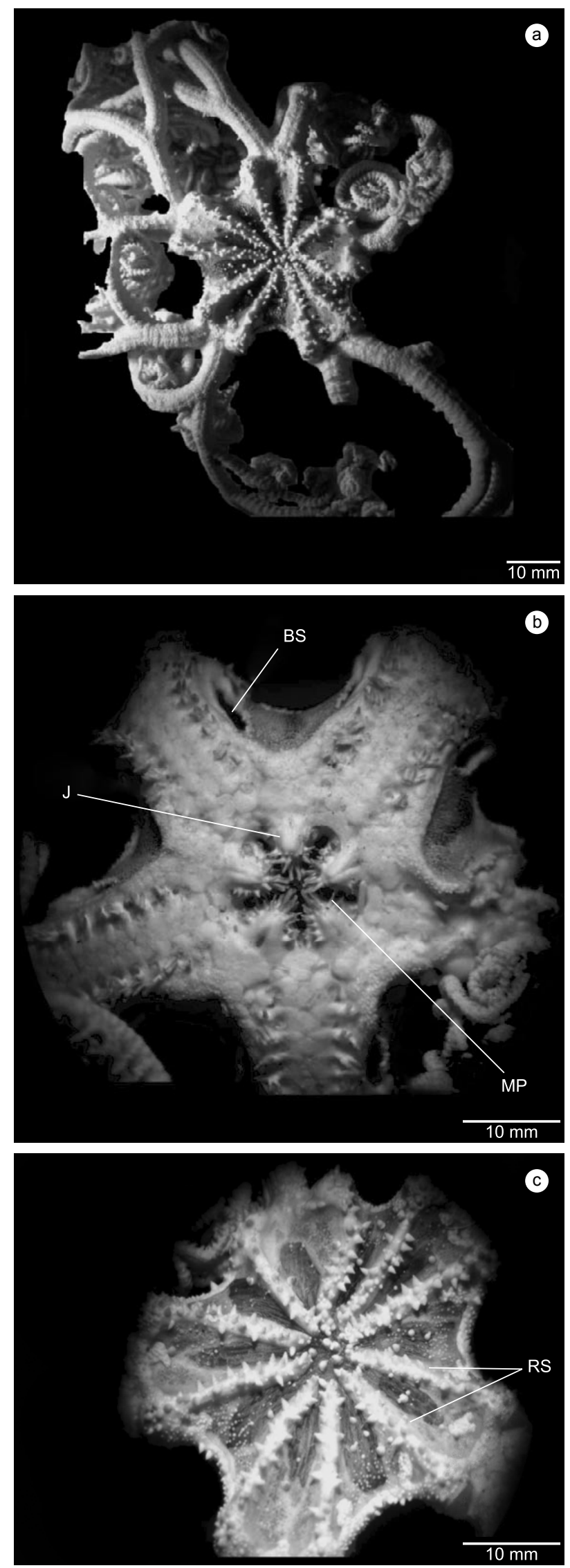

Figure 1. Gorgonocephalus chilensis (Philippi). a) aboral view; b) oral view: J- Jaw; MP- mouth papillae; BS- bursal slit; and c) aboral view. RS- radial shields.

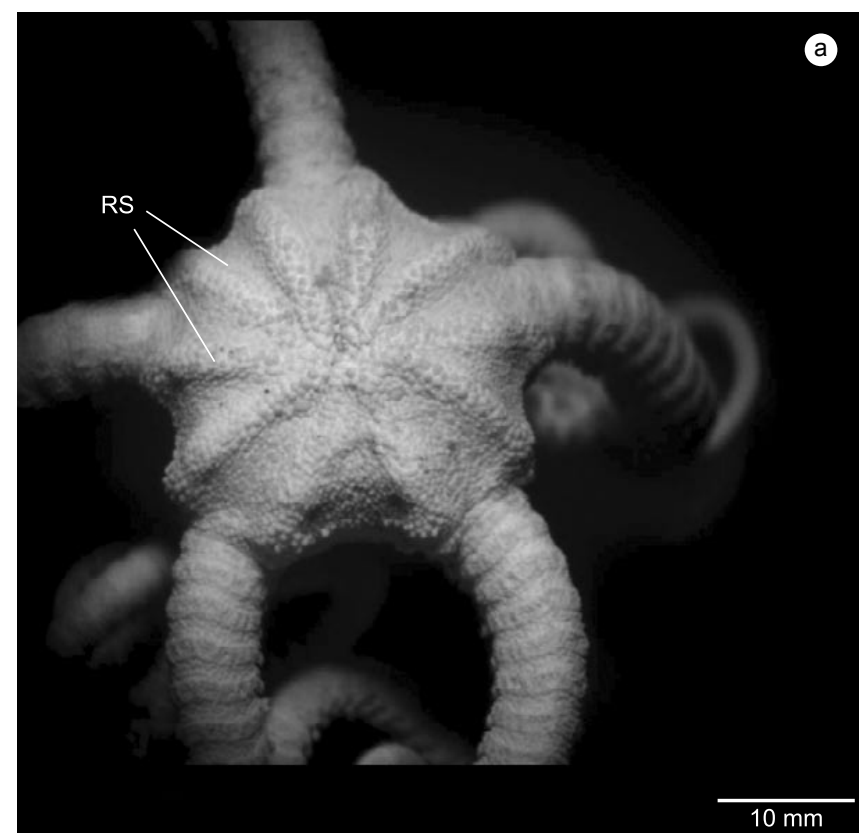

(b)

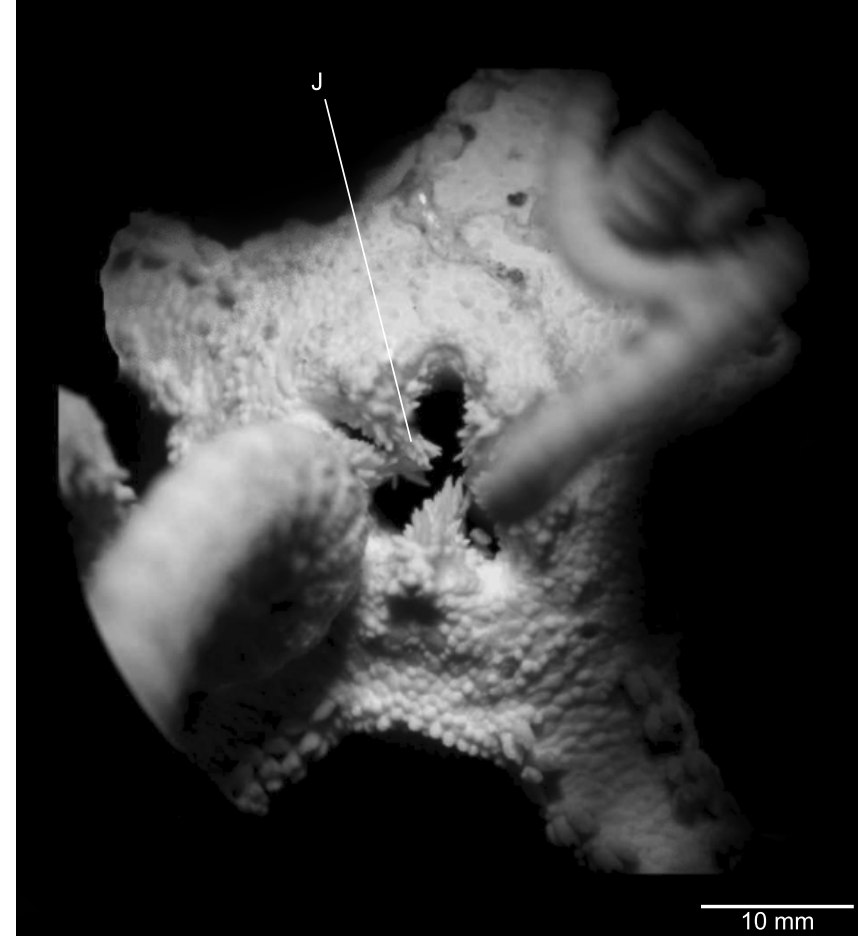

Figure 2. Astrotoma agassizii Lyman. a) aboral view: RS- radial shields; b) oral view: J- jaw.

lateral arm plate. The jaws are short and joined proximally. The teeth are triangular, arranged in one or two vertical rows. There are two or three papillae on the jaw's apex, flanked by up to five or more block-like contiguous oral papillae arranged in up to two horizontal rows on each side of the jaw. The first oral tentacle pore opens near the oral mouth angle. Four of the arms are coiled. Arm plates are covered by thick skin. The arms are four to five times as long as the diameter of the disc and lack dorsal plates. The lateral arm plates are large. The ventral arm plates are concealed by skin. There are no spines on the first arm segment. The second and third segments have one spine, and from 

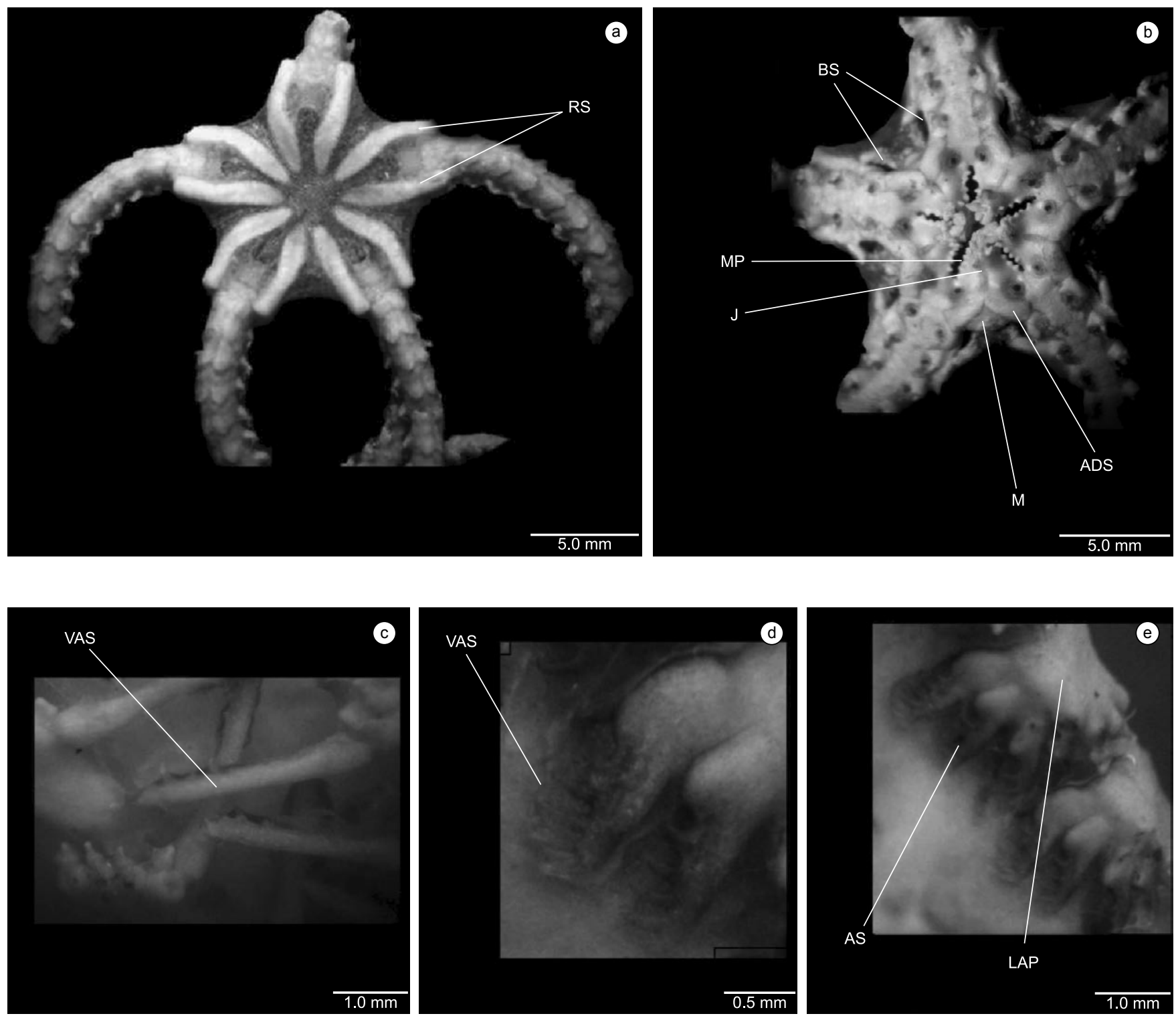

Figure 3. Asteronyx loveni Muller \& Troschel. a) aboral view: RS- radial shields; b) oral view: J- jaw. MP- mouth papillae; M- madreporite; BS- bursal slit; ADS- adoral shield. c-e) arm: VAS- ventral arm spine; AS- arm spine; LAP- lateral arm plate.

the fourth to the eighth segments there are two spines. From the ninth segment on, there are three thick and conical spines with small glassy teeth distally.

Distribution: Astrodia tenuispina has been recorded from both sides of the North Atlantic at depths of 2,452-3,659 m; in the east from the Rockall island to the Porcupine Sea Bight, the Bay of Biscay and off Portugal at depths of 1,560 to $3,548 \mathrm{~m}$ (Paterson 1985).

Order Ophiurida Müller \& Troschel, 1840

Suborder Ophiomyxina Fell, 1962

Family Ophiomyxidae Ljungman, 1867

Ophiomyxa vivipara Studer, 1876 (Figure 5a, b)

Material examined: Sta. \# 7178, 507m, UFSTAB-142 (1 specimen).

Biological observations: This is a viviparous species. In brooding ophiuroids the eggs are discharged into the bursae and remain there until they have developed into juveniles (Hyman 1955). This specimen of $23.5 \mathrm{~mm}$ in disc diameter had young inside the bursae.

Distribution: Margin off Chile from Chiloé to the South until the Strait of Magellan. Atlantic Ocean: margin off Argentina (San Jorge Gulf South to Tierra del Fuego, Burdwood, Malvinas, Kerguelen, Tristan da Cunha) and South Africa with a bathymetric range of 0-183 m (Bernasconi \& D'Agostino 1977, Jaramillo, 1981).

Suborder Ophiurina Müller \& Troschel, 1840

Family Ophiacanthidae sensu lato Perrier, 1891

Subfamily Ophiacanthinae Paterson et al., 1982

Ophiacantha sp. (Figure 6a, b)

Material examined: Sta. \# 7178, 507 m, EqMN 3009 (1 specimen). 
Manso, C.L.C.
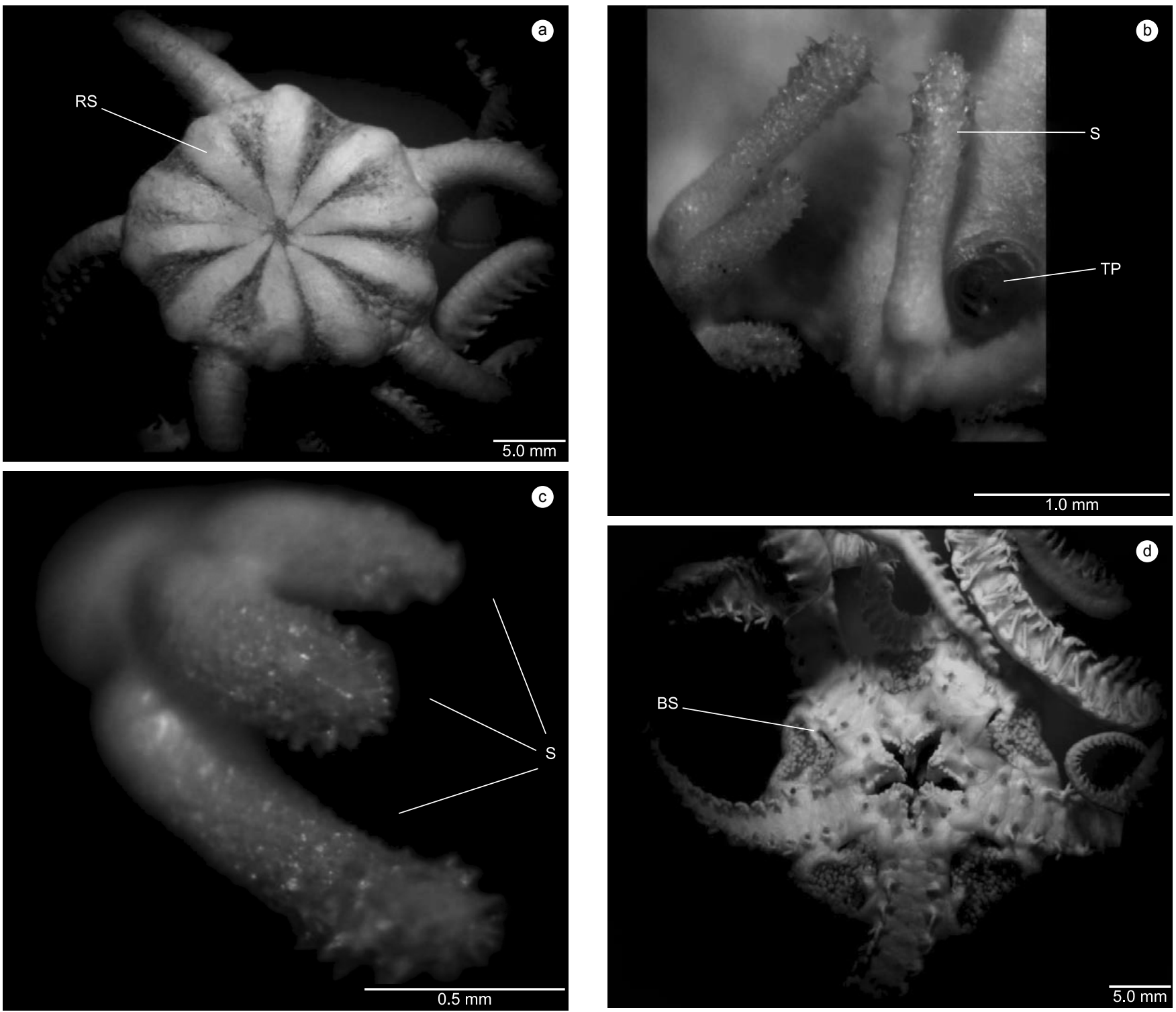

Figure 4. Astrodia tenuispina (Verril). a) aboral view: RS- radial shields; b) arm: S-spine, TP- tentacle pore; c) arm: S- spines; and d) oral view: BS- bursal slit.

Description: The disc is regular, 8,5 $\mathrm{mm}$ in diameter, with small, short, thick stumps, each bearing a crown of small thorns. The radial shields are hidden. The ventral interradial surfaces are covered by small scales and scarse spines. The bursal slits are wide and long. The oral shield are almost triangular. The adoral shields are almost retangular meeting in front of the oral shields. The jaws are small and have four to five thick and thorny mouth papillae. The thick infradental papillae are covered by small spines. There are five arms. The first and second dorsal arm plates are contiguous and have few granules, the others with bell shape are small and not contiguous. The ventral plates are almost pentagonal and are separated by the lateral ones. The lateral plates only meet by the ventral side, with five to six thorny, opaque and cylindrical arm spines.

There is one small thorny and pointed tentacle scale.

Remarks: The present specie was not identified because we had only one individual. Ophiacantha sp. differs from the other Chilean species and the other species from adjacent areas like Ophiacantha vivipara Ljungman, 1870, O. iquiquensis Castillo-Alarcón, 1968, O. cosmica Lyman, 1878, O. rosea
Lyman, 1878, O. sentosa Lyman, 1878, O. marsupialis Lyman, 1875, O. antartica Koehler, 1922, O. ingrata (Koehler, 1923) and $O$. savagica Tommasi, 1976 by the following characters: from $O$. vivipara Ljungman, by the number of arms and arm spines (6 to 8 arms and 9 to 12 arm spins in $O$. vivipara), from $O$. iquiquensis, $O$. cosmica, $O$. rosea by the number of arm spines ( 7 in O. iquiquensis, 8 in O. cosmica and 11 in O. rosea), from $O$. marsupialis by the number of arm spines and oral papillae ( 3 arm spines and 11 oral papillae in O. marsupialis), from $O$. antartica by the spines of the disc and number of arms (slender spines with 3 or 4 terminal spinelets and 5 to 6 arms in $O$. antartica), from $O$. ingrata by the number of arms and arm spines ( 6 to 7 arms and 7 to 8 arms spines in O. ingrata ) and from $O$. savagica by the number of arm spines (4 in $O$. savagica).

Subfamily Ophiotominae Paterson, 1985

Ophiolimna bairdi (Lyman, 1883) (Figure 7a - c)

Materia examined: Sta. \# 7105, 1,775 m, UFSITAB-141 (1 specimen). 

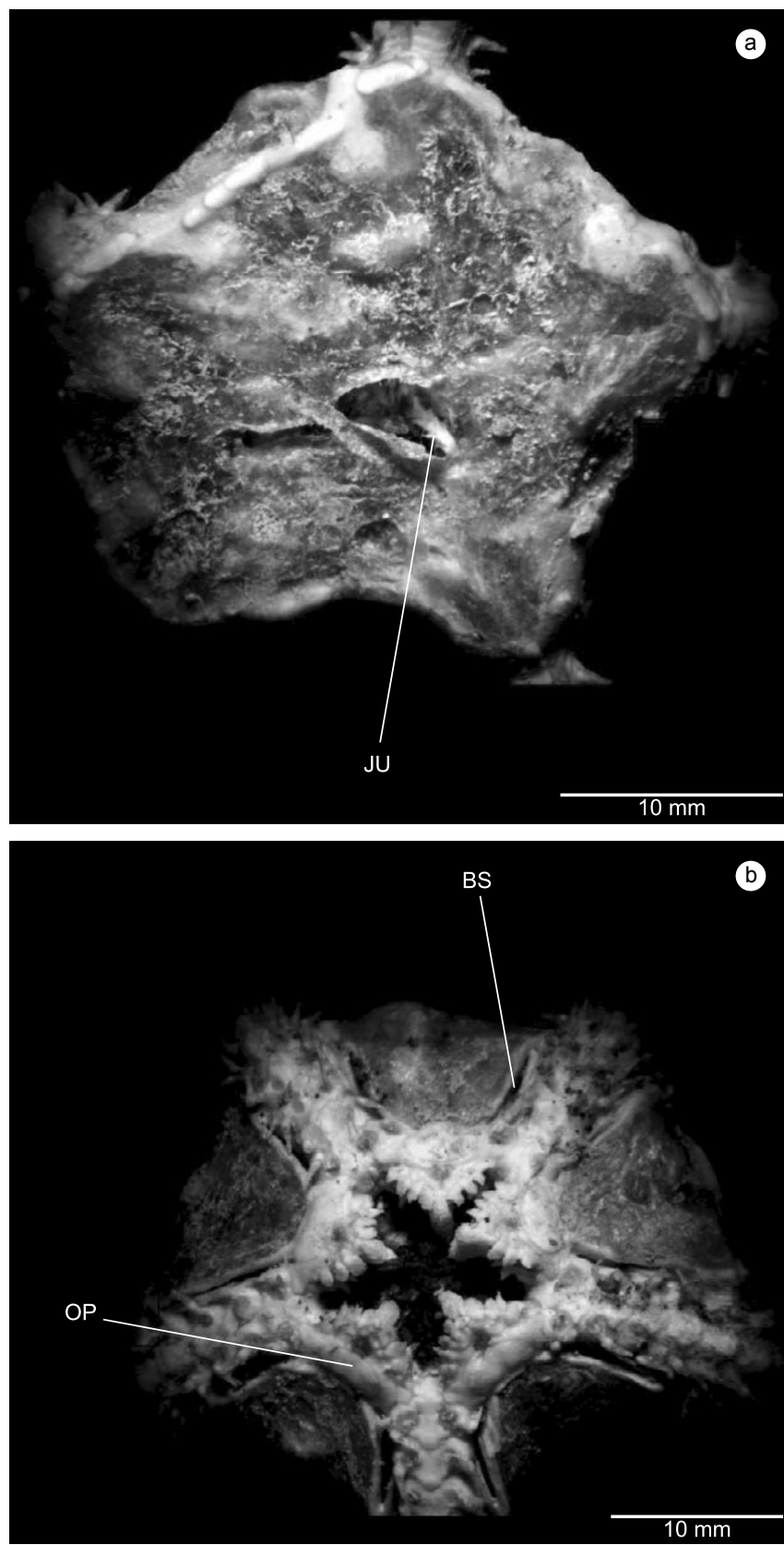

Figure 5. Ophiomyxa vivipara Studer. a) aboral view, JU- juvenile; and b) oral view: OP- oral plate; BS-bursal slit.

Description: The disc is sub-pentagonal, $8,5 \mathrm{~mm}$ in diameter. On the much damaged dorsal surface only the radial shields, as well as, some small scales covered by spines and elongated granules could be observed. The radial shields are longer than wider and covered with small scales and spines. The ventral interradial surfaces are covered with small scales and spines, similar to those of the dorsal surface. The oral shields are sub-triangular. The adoral shields have concave distal lateral edges and bear numerous granules on their contiguous proximal ends. The adoral shields separates the oral shields from the first ventral arm plate. The jaws are longer than wider, with one or two pointed infradental papillae. There are five to six oral papillae with the first two or three pointed. The following oral papillae are more rounded, except for the largest distal one, which is
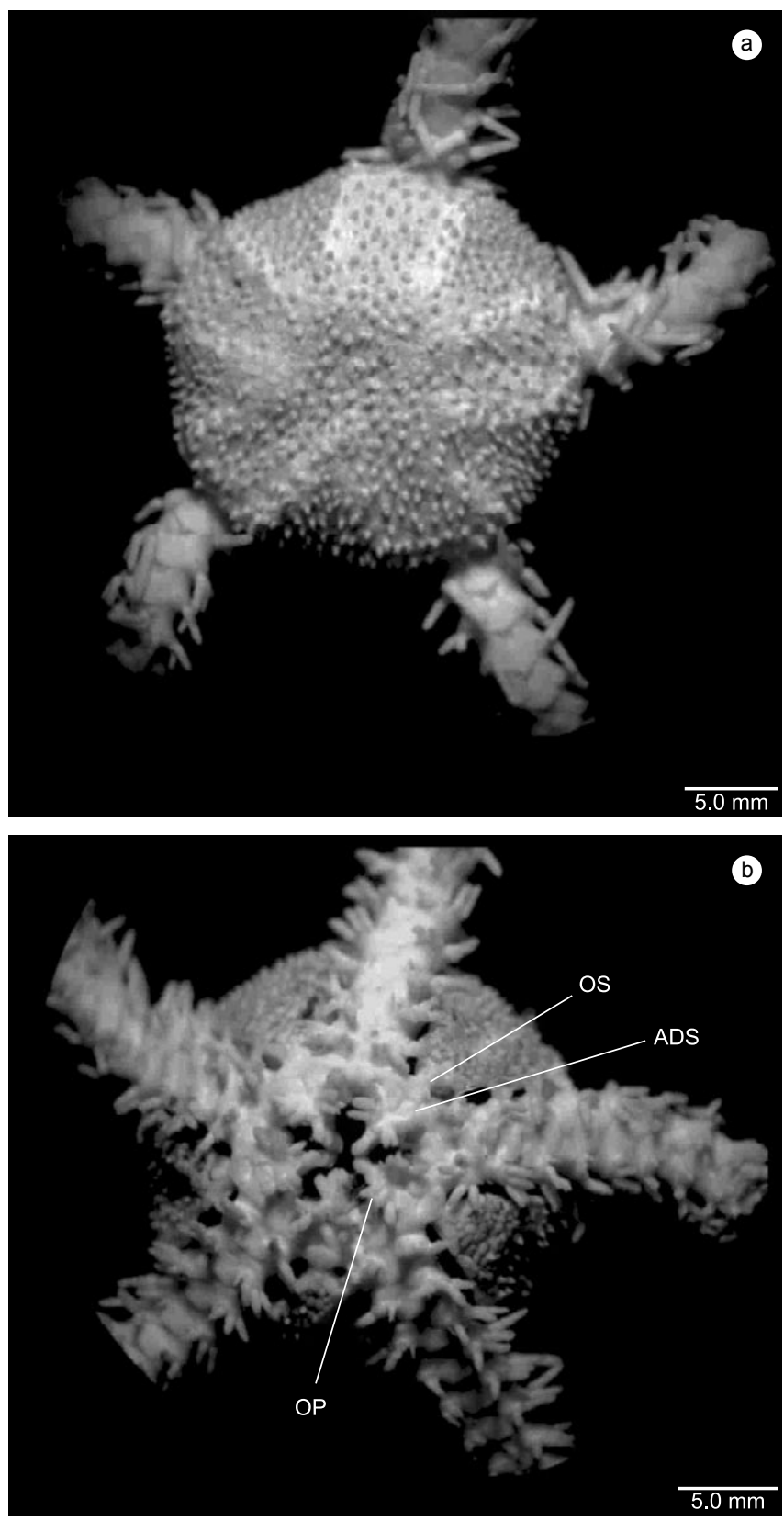

Figure 6. Ophiacantha sp. a) aboral view; and b) oral view. OS- oral shield; ADS- adoral shield; OP- oral papillae.

almost triangular with rounded edges. The arms with a slightly nodal appearance are partially broken. The dorsal arm plates are sub-triangular. The ventral plates are almost pentagonal with a rounded distal edge. A large tentacle pore is armed with a leaf-shaped scale. The lateral and ventral plates, and the tentacle scales are distinctly striated, causing these structures to shine. There are six arm spines.

Remarks: Ophiolimna baird has great resemblance with O. antarctica (Lyman, 1879) according to O`Hara \& Stöhr (2006). The main difference between these two species, is the elongated spines, which occur among the low disc granules in $O$. bairdi but never in O. antarctica (O'Hara \& Stöhr 2006). The wide distribution of the Ophiolimna antarctica, includes NE Indian Ocean, Japan, the NW Pacific, New Caledonian, New 

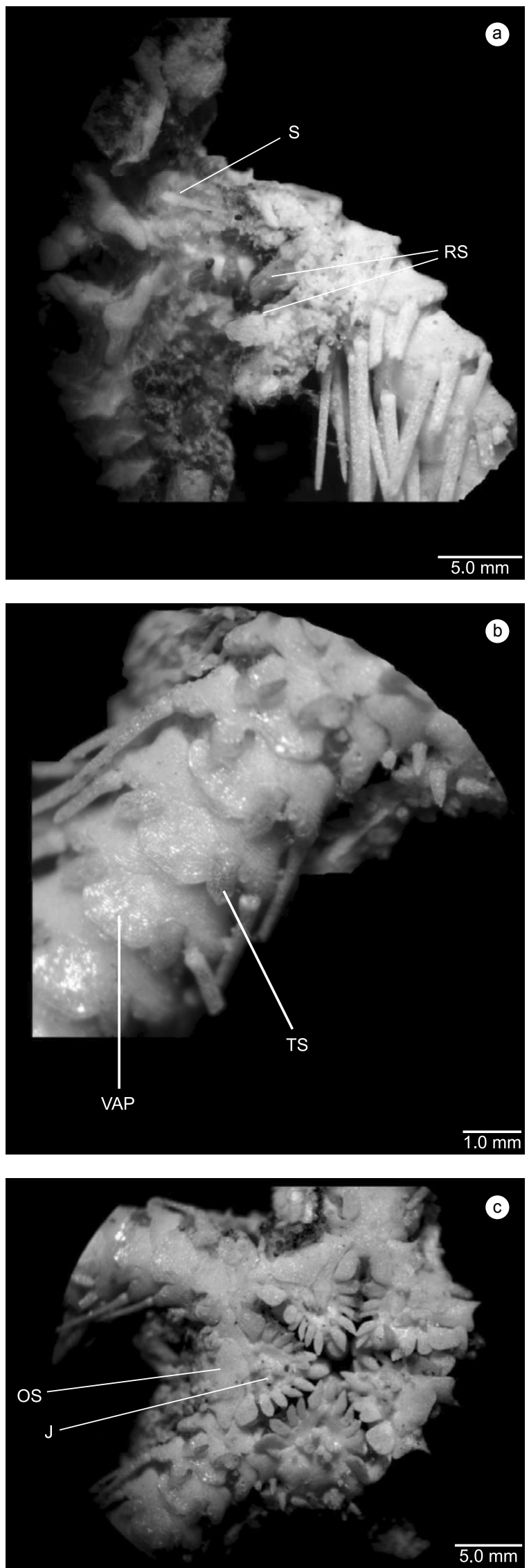

Figure 7. Ophiolimna bairdi (Lyman). a) aboral view : S- spine; RS-radial shield; b) ventral arm side: VAP- ventral arm plate; TS- tentacle scale; and c) oral view: OS- oral shield; J- jaw.
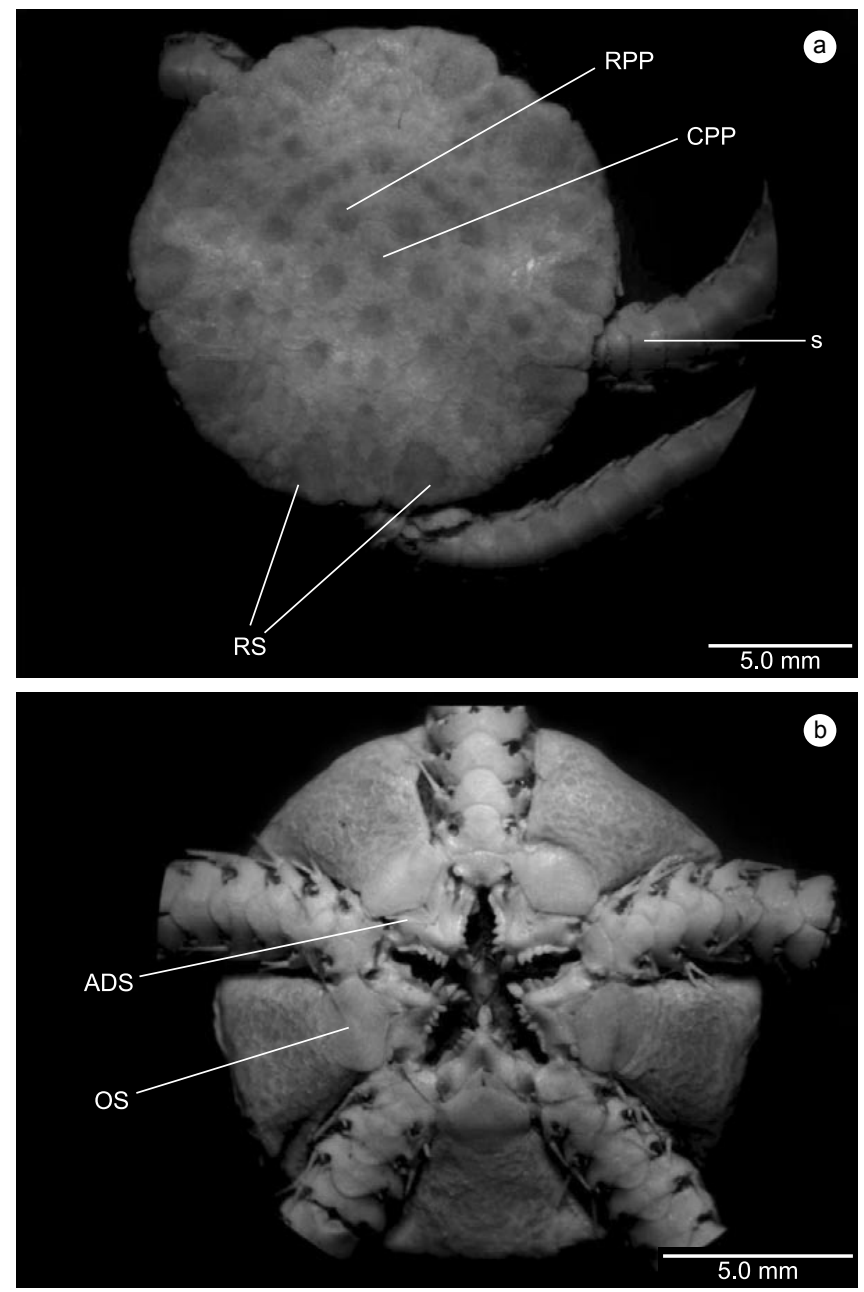

Figure 8. Ophiocten amitinum Lyman. a) aboral view: RS- radial shields; CPP- central primary plate; RPP- radial primary plate; arm: S- spines; and b) oral view: OS- oral shield; ADS- adoral shield.

Zealand, as well as Antarctic and Sub-Antarctic areas, in depths of 180 to $2,926 \mathrm{~m}$.

Distribution: Paterson (1985) suggested that this species originated in Africa. It has been found in bathyal and abyssal depths on both sides of the North Atlantic. With this record its distribution is extended to the eastern South Pacific Ocean.

Suborder Chilophiura Matsumoto 1915

Family Ophiuridae Lyman 1865

Ophiocten amitinum Lyman 1878 (Figure 8a, b)

Material examined: Sta. \# 7105, 1,775 m, EqMN 3003 (14 specimens); Sta. \# 7166, 1,424 m, EqMN 3004 (11 specimens); Sta. \# 7167, 2,225 m, EqMN 3002 (74 specimens); UFSITAB-92 (48 specimens).

Description: The disc is round and flat, covered by scales of various sizes measuring from 3 to $15 \mathrm{~mm}$ diameters. The central dorsal plate and circle of primary plates are separated by smaller scales. The radial shields range from an oval to a sub-triangular shape and are separated from each other by a series of scales. The arm combs are formed by seven to eight thin spines and can be observed to either side of an arm base, below the radial shields. The ventral interradial surface is covered by scales similar to 
those on the dorsal surface. The bursal slits are long. The oral shields are pentagonal, pointed, and at their distal edge slightly convex. The adoral shields are rectangular, slim and contiguous, separating the oral shield from the first ventral arm plate. The jaws are long and thin. There is a single conical apical papilla and four to five lateral sub-rectangular papillae on each side of the jaws. The second oral tentacle pore is situated outside the mouth slit, with one or two scales attached on the first ventral arm plate and one to two on the adoral shield.

The dorsal arm plates nearest to the disc were wider than longer. On the distal segments the dorsal plates are as wide as long. At the distal edge of these plates until the proximity of the fourth or fifth segments, small and thin spines can be observed. The first ventral arm plate is trapezoid and the following are new moon-shaped and not contiguous. The lateral arm plates are short, wide and with three pointed spines, the dorsal one largest. The tentacle pore is large with three small scales up to the two or three segment, after that the proximal scale is atrophied, leaving only one scale along the arm like show the following formula: A.P. $1=\mathrm{L} 1$, V2; A.P. 2 = L1, V2; A.P. $=$ L1, V1; A.P. $4=\mathrm{L} 1$, V1-0; A.P.5 = L1, V0.

Distribution: Smith Channel, Magellan Strait, Beagle Channel, around the Malvinas Islands (44-52 ${ }^{\circ} \mathrm{S}$ and $56-63^{\circ} \mathrm{W}$ ) (Discovery Expedition); off the Buenos Aires Province and South Georgia Islands, Kerguelen, Prince Edward and Crozet (Bernasconi \& D'Agostino, 1977). This study extends the distribution of $O$. amitinum to the Pacific Ocean between $22^{\circ}$ and $36^{\circ} \mathrm{S}$ while enlarging its bathymetric range from $46-545 \mathrm{~m}$, to $2,225 \mathrm{~m}$.

Ophiura (Ophiuroglypha) lymani Ljungman 1871 (Figure 9a, b)

Material examined: Sta. \# 7105, 1,775 m, EqMN 3008 (1 specimen); UFSITAB-89 (1 specimen).

Distribution: Chilean Islands and Strait of Magellan; Atlantic Ocean from Tierra del fuego to Argentina (Buenos Aires province $37^{\circ} \mathrm{S}$ ), South Georgia and Malvinas Islands. With a bathymetric range 0-463 m (Bernasconi \& D’ Agostino 1977).

Ophiura (Ophiuroglypha) arntzi sp. nov.(Figure 10 a - e)

Holotype: Sta. \# 7103, 846 m, EqMN 3000, 04.02.2001.

Paratype: UFSITAB-88(1 specimen), collected in the same station that holotype.

Type locality: Chilean margin, $22^{\circ} 51^{\prime}$ '99' S and 70 32 ' 58” W.

Etymology: The name honors Prof. Dr. Wolf Arntz, formerly with the Alfred Wegener Institute for Polar and Marine Research, Bremerhaven, Germany, one of the organizers and cruise-leaders of this expedition.

Diagnosis: A pentagonal disk is covered by large and small scales of diverse shapes. The radials shields are wider than long, separated by two large and inflated scales proximally and by the first dorsal arm plate distally. The radial area is strongly elevated with irregular scales, almost all of them large. The lateral arm plates have three small, thick spines on the proximal end and from the ninth arm segment the central spines are transformed into a small hook.

Description of the holotype: The holotype has a pentagonal disc with $9.5 \mathrm{~mm}$ of diameter, covered by large and small scales of diverse shapes. The radial shields are wider than long, separated proximally by two large inflated scales and distally by the first dorsal arm plate. The radial area is strongly elevated with irregular scales, almost all of them large. All primary plates are rounded and large. Between the primaries and the central dorsal plate there are additional smaller scales. These smaller scales extend to the inter-radial area. The median distal interradial area of the disc is
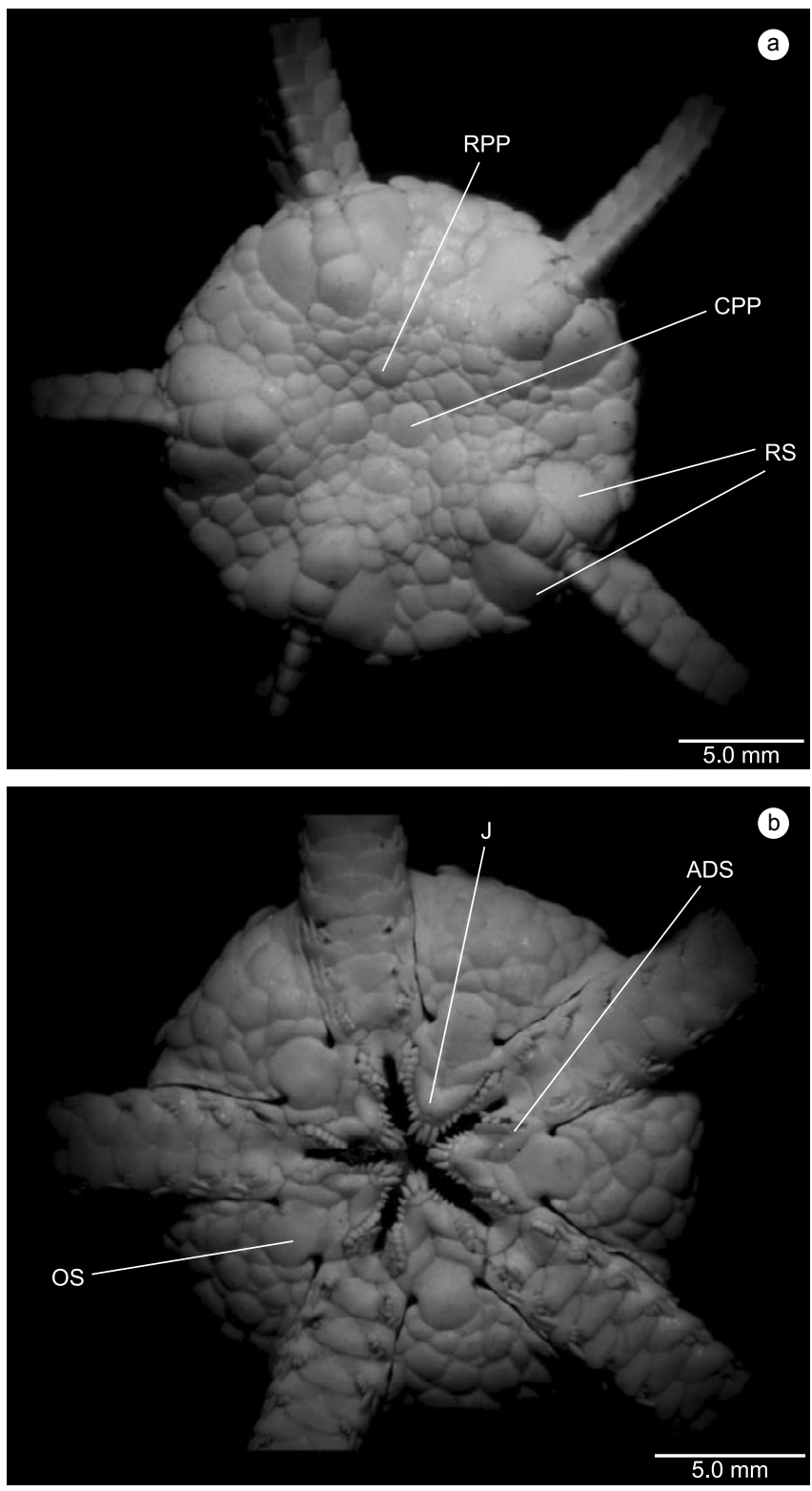

Figure 9. Ophiura (Ophiuroglypha) lymani Ljungman. a) aboral view: CPPcentral primary plate; RPP-radial primary plate; RS- radial shields; and b) oral view: OS- oral shield; ADS - adoral shield; J- jaw.

formed by large and inflated scales with emphasis on the most distal scale that is semi-rectangular and extremely inflated. The ventral interradial surface is covered by inflated scales, slightly smaller than those of the dorsal area. The bursal slit is bordered by small pointed spines that progressively become bigger to form the arm comb. The oral shields are long and large, rounded and narrower in their proximal part, with strongly concave lateral edges. The adoral shields are small, narrow, semi-rectangular and contiguous. The jaws are slender, contiguous and slightly elevated on their proximal ends with two pointed infradental papillae those are sitting on the dental plate, followed by five to six oral papillae, the first and the second ones narrow. The following papillae are rounded and the three last ones are in the shape of continuous blocks. The second oral tentacle pore is big, opening outside the mouth slit with four or five scales on each side. 

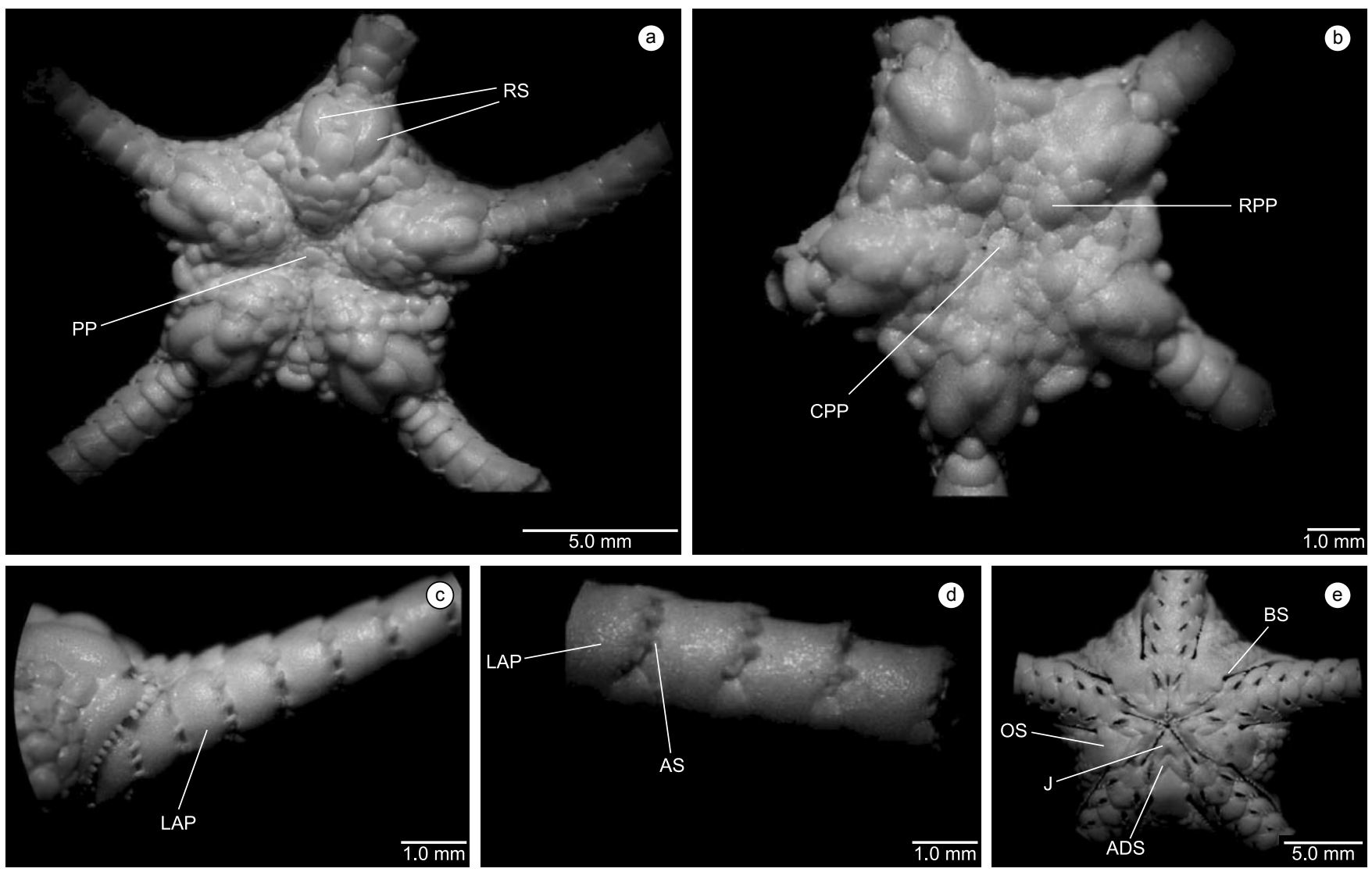

Figure 10. Ophiura (Ophiuroglypha) arntzi sp. nov. a) Holotype, aboral view: CPP- central primary plate; RS- radial shields; b) paratype: CPP- central primary plate; RPP- radial primary plate; c) arm: LAP- lateral arm plate; d) arm: LAP- lateral arm plate; AS- arm spine; e) oral view: BS- bursal slit; OS- oral shield; ADS - adoral shield; J- jaw.

The first three or four ventral arm plates are wider than long and continuous. The following ones are broader than long and increasingly separated distally. Proximally the lateral arm plates are not in contact with each other ventrally, but after the third segment they are in contact. They have three small, thick spines on the proximal end and from the ninth arm segment the central spines are transformed into a small hook. The ventral arm plates are wider than long on the first proximal segments, strongly decreasing in size distally. The tentacle pores present on the first five arm segments of the smaller specimen, and on the first seven segments of the largest specimens, the following formula: A.P. $1=$ L6-4, V5-4; A.P. $2=$ L4, V3; A.P. $3=$ L3, V2; A.P. $4=$ L3, V2; A.P. $5=$ L3, V2; A.P. $6=$ L2, V1; A.P. $=$ L2-1, V0.

Variation in the paratype: Hooks appear on the third arm segment in the specimen with $6.5 \mathrm{~mm}$ of disc diameter.

Remarks: Ophiura (Ophiuroglypha) arntzi sp. nov. is close to O. (O.) lymani Ljungman 1871, O. (O.) clemens (Koehler 1904), Ophiura (O.) irrorata irrorata (Lyman 1878), and Ophiura (O.) irrorata concreta (Koehler 1901), in sharing the shape of disc scales. The present new species differs from $O$. (O.) lymani by the shape of the arm comb papillae (block-shaped in $O$. (O.) lymani), the radial shields and disc plates (shorter in $O$. (O.) lymani), and the dorsal arm plates (extremely elevated in $O$. (O.) lymani); from $O$. (O.) clemens by the shape of the oral shield, the shape of the arm comb, and the shape of the oral papillae (block-shaped in $O$. (O.) clemens); from $O$. (O.) irrorata irrorata, by the height of the disc (lower in $O$. (O.) irrorata irrorata) and the size of the aboral disc scales (smaller in $O$. (O.) irrorata irrorata); from Ophiura (Ophiuroglypha) polyacantha Mortensen, 1933 by the high of the dorsal disc scales (lower in $O$. (O.) polyacantha) and by the number of arm spines (nine in $O$. (O.) polyacantha). Finally, $O$. (O.) arntzi sp. nov. differs from Ophiura (Ophiuroglypha) irrorata concreta (Koehler 1901), by the size and disposition of the dorsal scales of the disc (larger or smaller in $O$. (O.) irrorata concreta), by the shape and size of the oral shields (pentagonal and as broad as long in $O$. (O.) irrorata concreta ) and by the disposition of the spines.

Stegophiura wilhelmi sp. nov. (Figure 11a-c)

Holotype: Sta. \# 7177, 995 m, EqMN 2999, 05.03.2001.

Paratype: UFSITAB-96 (1 specimen), collected in the same station that holotype.

Type locality: Chilean margin, $42^{\circ} 34^{\prime} 93^{\prime \prime} \mathrm{S}$ and $74^{\circ} 50^{\prime} 25^{\prime \prime} \mathrm{W}$.

Etymology: The name honors Dr. Ottmar Wilhelm, one of the founders of Marine Sciences at the University of Concepción.

Diagnose: The slightly pentagonal disc has rounded borders and is covered with irregular, somewhat granulated and inflated scales. The central plate is semi-pentagonal, slightly convex, with the same size or larger than the primaries. The lateral arm plates are of the same width as the dorsal ones, with each plate with one to three or no spines.

Description of the holotype: The slightly pentagonal disc with $21 \mathrm{~mm}$ of the diameter has rounded borders and is covered with 

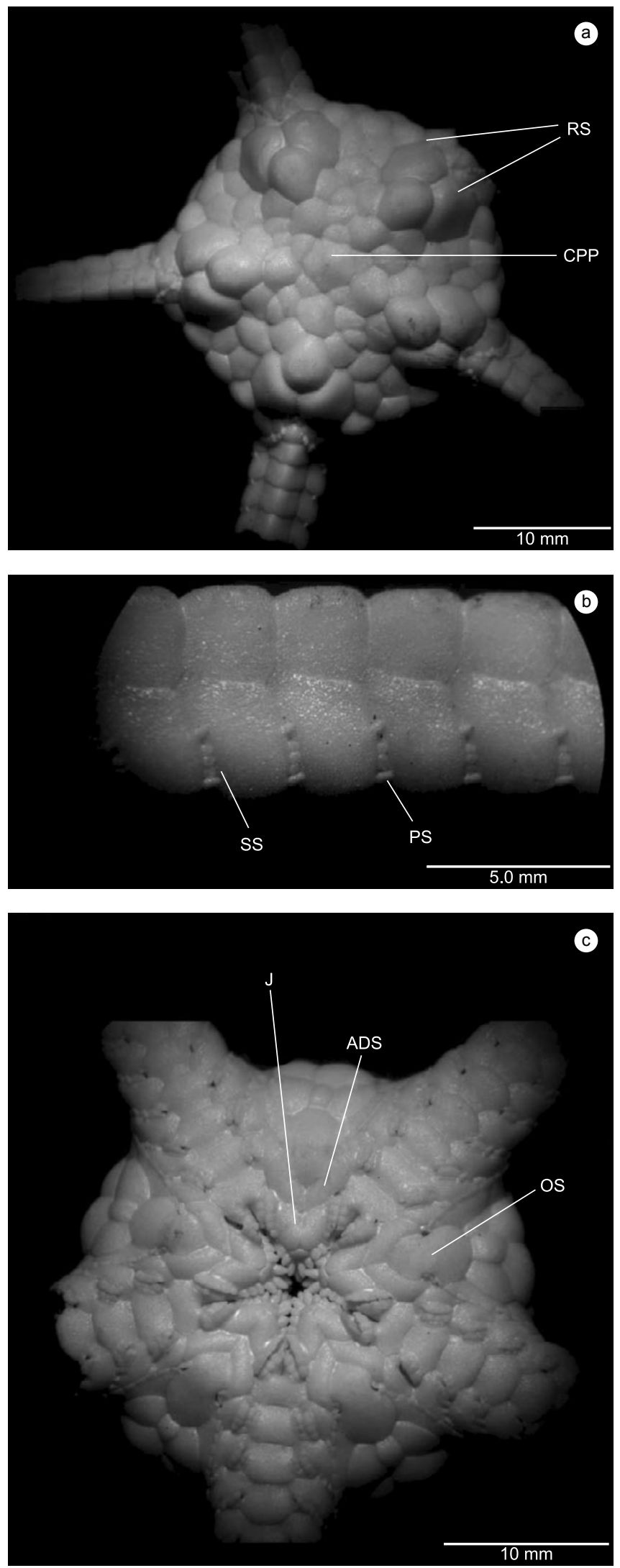

Figure 11. Stegophiura wilhelmi sp. nov. a) aboral view: CPP- central primary plate; RS- radial shields; b) arm: SS- secundary spine; PS- primary spine; and c) oral view: OS- oral shield; ADS- adoral shield; J- jaw. irregular, somewhat granulated and inflated scales. The central plate is semi-pentagonal, slightly convex, with the same size or larger than the primaries and it is separated from those by five small irregular scales. The primaries are followed in the radial area by larger sub-pentagonal scales, with rounded distal borders, positioned on the proximal zone between the radial shields of the same pair. The radial shields are longer than wide, inflated, and contiguous over their distal third. Each pair of radial shields is separated from neighboring pairs by five scales arranged in the following way: one large proximal scale, two middle ones and three distal scales. These distal scales form the disc edge. The ventral interradial surface is covered with five to six large irregular scales. The bursal slits are narrow and long bordered by flat, rectangular and continuous genital scales that extend to the dorsal surface of the disc were they become narrower and pointed, forming the arm comb. The jaws are longer than wide, formed by strong and inflated plates. The infradental papillae are pointed in number of two on the apex of the jaws, followed by three to two oral papillae with rounded borders on each side of the jaws. The first oral tentacle pore communicates with the oral slit and is bordered by four to five papillae connected with the jaws and adoral shields. Also four papillae are placed on the first ventral arm plate. The adoral shields are inflated, narrow and continuous, close to each other, covering the proximal third of the oral shield and touching the first ventral arm plate and also the first lateral arm plate. The oral shields have a proximal area that gives the shield an arrow-like aspect, with the distal edge well rounded. The rest of the ventral surface is covered by five large scales.

The arms were broken on the studied specimens. The dorsal arm plates are strongly convex, wider than long, on the proximal half of the arm as long as wide. The lateral arm plates are of the same width as the dorsal ones, with each plate with one to three or no spines. On the first arm segment there may be one, two or three spines, which are very small, contiguous and thick; three to four on the second segment; five to six on the third; seven to fourteen on the fourth segment and onwards, varying in size. From the fourth segment the uppermost spine and the middle ones (primaries) are pointed and larger than the others (secondary). The latter are positioned in rows between the primary spines that are connected to the lateral plates. On the fourth arm segment of the largest specimen, a row with up to seven secondary spines above the upper primary ones can be observed. On the fifth segment up to two secondary spines above the upper ones can be observed above the superior primary. The ventral plates of the arms are wider than long and hexagonal on the first segments. There are tentacle pores along the entire arm with tentacle scales distributed according to the following formula: A.P. $1=$ L6-4, V4; A.P. $2=\mathrm{L} 4$, V3; A.P.3 = L4-3, V3-2; A.P.4 = L4-3, V1; A.P.5, 6, 7, 8, 9 = L3, V1; A. P.10 = L2, V0.

Remarks: The smaller specimen examined had a disc diameter of $15 \mathrm{~mm}$.

According to Djakonov (1954) the genus Stegophiura Matsumoto, 1917 possesses few species, mostly in the North Pacific, in particular off Japan. More recently a species was registered in Marion island, subantarctic region (Branch et al., 1993). Only a few species are found in the North Atlantic and also four species belong to the fauna of the former Soviet Union. This is the first time that this genus is recorded in the Eastern South Pacific.

Stegophiura wilhelmi sp. nov. is very close to S. brachyactis (H.L. Clark, 1911), Stegophiura elevata (Lyman, 1878), S. nodosa (Lütken, 1854) and S. sterea (H.L. Clark, 1908) in sharing the shape of the disc plates. The present new species differs from $S$. brachyactis 
by the size of the central plate (smaller in S. brachyactis) and by the shape of the ventral arm plates (tetrahedral in S. brachyactis). Stegophiura wilhelmi sp. nov. differs from Stegophiura elevata by the size of disc plates (smaller in S. elevata). Stegophiura wilhelmi sp. nov. differs from $S$. nodosa (Lütken 1854) by the position and the shape of the adoral shields (rounded and with no indentation, and located in front of the oral shields in $S$. nodosa), and by the number of brachial spines (smaller in $S$. nodosa). Stegophiura wilhelmi sp. nov. differs from S. sterea (H.L. Clark 1908) by the shape of the arm comb (very narrow and pointed in S. sterea), by the number and shape of the arm spines (four to five pointed primary spines and fifteen pointed secondary spines in S. sterea). Stegophiura wilhelmi sp. nov. differs from $S$. stuwitzii (Lütken 1857) by the size of the radial shields (very narrow and short in S. stuwitzii), by the number of oral papillae (approximately seven in S. stuwitzii), by the disposition of the arm spines (completely separated, not forming a series in S. stuwitzii), and finally, by the presence of a crest on the first ten ventral arm plates in S. stuwitzii. Stegophiura wilhelmi sp. nov. differs from S. sladeni (Duncan 1879) by the shape and number of the papillae on the arm comb (pointed and numerous (13) primary spines in S. sladeni), and also, by the ventral arm plates (with an elevation in S. sladeni). Stegophiura wilhelmi sp. nov., differs from S. carinata Djakonov, 1954 by the latter's dorsal surface of the disc (covered with scales smaller and more numerous in $S$. carinata) by the primary scales (small in S. carinata), by the arm comb (formed by narrow and long papillae in $S$. carinata), by the dorsal arm plate of the mid-distal area (short and wide excavated in S. carinata), and by the proximal ventral arm plates (with a median elevation $S$. carinata). Stegophiura wilhelmi sp. nov. differs from S. macrarthra H. L. Clark, 1915 by the shape of dorsal disc plates (larger in S. macrarthra), by the number of primary spines ( 3 to 4 primary spines and a crest on the middle region of the proximal ventral arm plate in $S$. macrarthra). Stegophiura wilhelmi sp. nov. differs from S. vivipara Matsumoto, 1915 by the arrangement and number of the dorsal interradial plates (large square plate separating the pair of radial shields and the pairs next to it in $S$. vivipara) and by the number of oral papillae (5 in S. vivipara).

\section{Amphiophiura gallardoi sp. nov. (Figure 12a-c)}

Holotype: Sta. \# 7166, 1,424 m, EqMN 2995, 06.25.2001.

Paratypes: EqMN 2996 (9 specimens) and UFSITAB-84 (7 specimens), collected in the same station that holotype.

Type locality: Chilean margin, $36^{\circ} 27^{\prime} 99^{\prime \prime} \mathrm{S}$ and $73^{\circ} 46^{\prime} 47^{\prime \prime} \mathrm{W}$.

Etymology: The name honors Prof. Dr. Víctor Ariel Gallardo, of the Department of Oceanography of the University of Concepción, one of the main organizers and cruise-leaders of the PUCK expedition.

All of them with disc diameters between 6 and $13.5 \mathrm{~mm}$.

Diagnosis: The disc is pentagonal and covered by large, tumid scales mixed with very small ones. The primary plates are well defined. Between the central primary plate and the radial primaries, numerous small scales can be observed; some resembling just small grains.

Description of the holotype: The disc is pentagonal and covered by large, tumid scales mixed with very small ones. Disc with $11 \mathrm{~mm}$ of the diameter. The primary plates are well defined. Between the central primary plate and the radial primaries, numerous small scales can be observed; some resembling just small grains. The radial shields are small and longer than wide, separated by three to five large scales of varying size and shape, the middle one being larger than the others. The larger scales are almost always tumid. The interradial dorsal surface area contains two large scales, extremely well defined and surrounded by small scales of diverse shape. The ventral area is
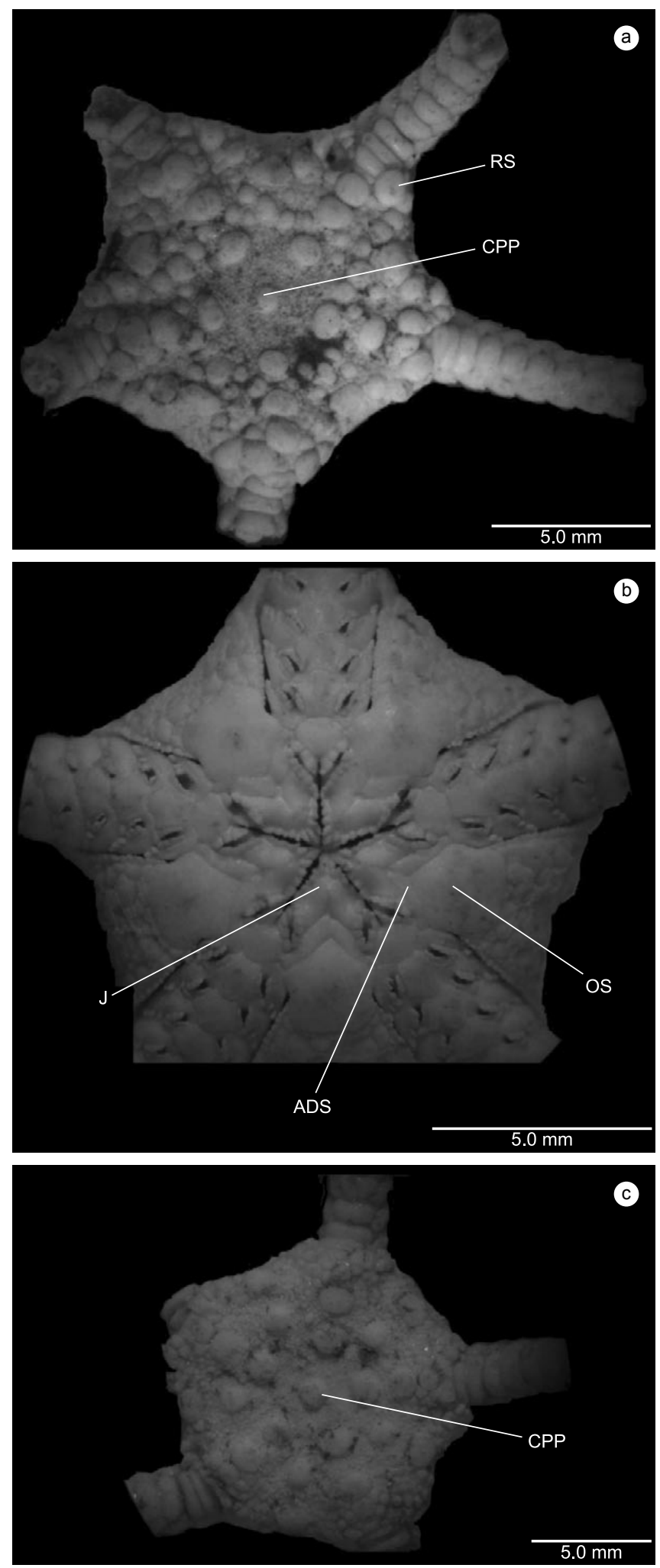

Figure 12. Amphiophiura gallardoi sp. nov. a) Holotype, adoral view: CPP- central primary plate; RS- radial shields; b) oral view: OS- oral shield; ADS - adoral shield; J- jaw; and c) Paratype, aboral view: CPP- central primary plate.

covered by scales, similar to those of the dorsal surface, except that these are smaller. The bursal slits extend from the oral shields to the dorsal surface of the disc. The genital scales are long, with a series of small, quadrangular to rounded scales arranged continuously 
distalwards forming the arm comb. The oral shields are large and sub-pentagonal with a slight lateral indentation and with a narrow proximal edge. The adjacent adoral shields are narrow. The jaws are short and slightly elevated in their proximal part. The teeth are large and pointed. There are one or two pointed infradental papillae, and four to six oral papillae with the proximal ones slightly narrower. The remaining papillae are semi-rectangular, all located in the middle of the proximal portion of the jaws, ranging from very small to very big ones. The second oral tentacle pore is large and close to the oral slit. Seven scales are attached to the distal part of the jaws, and the proximal part of the adoral shields; and four to five scales are associated with the first ventral arm plates.

The arms of the holotype are broken. The first four dorsal arm plates are rectangular and tumid; following ones range from sub-triangular to triangular, decreasing in size along the arm. The lateral arm plates are large, and from the fourth to the seventh segments they are contiguous on the ventral area with five to seven short and thick arm spines. The first ventral arm plate is hexagonal, the following ones become pentagonal. The tentacle scales are distributed in the following way: A.P.1 $=$ L5, V5; A.P. $2=$ L5, V5; A.P. $3=$ L5, V5; A.P. $4=$ L4, V3-4; A.P. $5=$ L4, V3; A.P. $6=$ L3, V2; A.P.7 = L3, V1; A.P. $=$ L3, V1; A.P. $11=$ L2, V1; A.P. $17=$ L0, V0.

Variations in the Paratypes: Differences among the scales of the dorsal surface of the disc relate mainly to their form, size, height and position. These variations were found in practically all specimens but allowed to recognize two basic groups: (1) a first group composed of specimens where small, slightly high scales predominate, and (2) a second group with larger and high scales. All the specimens presented some differences.

Remarks: Amphiophiura gallardoi sp. nov. is close to A. bullata bullata (Wyville-Thompson, 1877), A. bullata convexa (Lyman, 1878), A. bullata vitjazi Litvinova, 1971, A. metabula H. L. Clark, 1915, A. saurura (Verrill, 1894), and A. sculptilis (Lyman, 1878) in sharing plates with varying sizes on the dorsal surface of the disc. Amphiophiura gallardoi sp. nov. differs from A. bullata bullata, A. bullata convexa, A. bullata vitjazi, A. metabula, A. saurura, and A. sculptilis, by the size and shape of the radial shields (bigger in A. bullata bullata, A. bullata convexa and A. bullata vitjaz; rectangular to teardrop shaped in A. metabula and A. saurura; rectangular in A. sculptilis). Amphiophiura gallardoi sp. nov. differs from Amphiophiura paucisquamata Ziesenhenne, 1940, by the size and number of dorsal scales (few large and pitted dorsal disc plates in A. paucisquamata) and in the small number of arm spines ( 2 or 3 A. paucisquamata). Amphiophiura gallardoi sp. nov. differs from Amphiophiura irregularis Ziesenhenne, 1940, by the size of the radial shields (large, slightly longer than wide, and broadly in contact in A. irregularis) and by the all the plates are finely granular in A. irregularis. Amphiophiura gallardoi sp. nov. differs from Amphiophiura oediplax (H.L. Clark, 1911) by the shape of radial shields (almost square in A. oediplax) and by the number of tentacles scales (two or three, and only one toward the arm tips in A. oediplax). Amphiophiura gallardoi sp. nov. differs from A. penichra (H.L. Clark, 1911) by the number of arm spines (one very papilliform in A. penichra). Amphiophiura gallardoi sp. nov. differs from A. pachyplax Djakonov, 1954 by the oral shields (wide distally in A. pachyplax) and by the number of arm spines (only one in A. pachyplax). Amphiophiura gallardoi sp. nov. differs from A. ponderosa (Lyman, 1878) by the plate pattern of the ventral side of the disc (interradially covered with four large plates in A. ponderosa). Amphiophiura gallardoi sp. nov. differs from
A. megapoma (H.L. Clark, 1911) by the number of arm spines (4 to 5 in A. megapoma), by the smaller number of the oral papillae ( 3 small and obtuse papillae in A. megapoma) and by the lack of scales on the inner side of the tentacle pores, even on the proximal joints in A. megapoma. Amphiophiura gallardoi sp. nov. differs from A. gibbosa Mortensen, 1936 by the adoral plates of the disc (bigger in A. gibbosa), and by the number of the oral papillae (three in A. gibbosa). Amphiophiura gallardoi sp. nov. differs from $A$. rowetti Smith, 1923, by size of adoral scales of the disk (bigger in A. rowetti).

Suborder Gnatophiurina Matsumoto, 1915

Super family Gnathophiuridea Matsumoto, 1915

Family Amphiuridae Ljungman, 1867

Amphioplus magellanica (Mortensen, 1936) (Figure 13a, b). Material examined: Sta. \# 7105, 1,775 m, UFSITAB-87 (1 specimen).
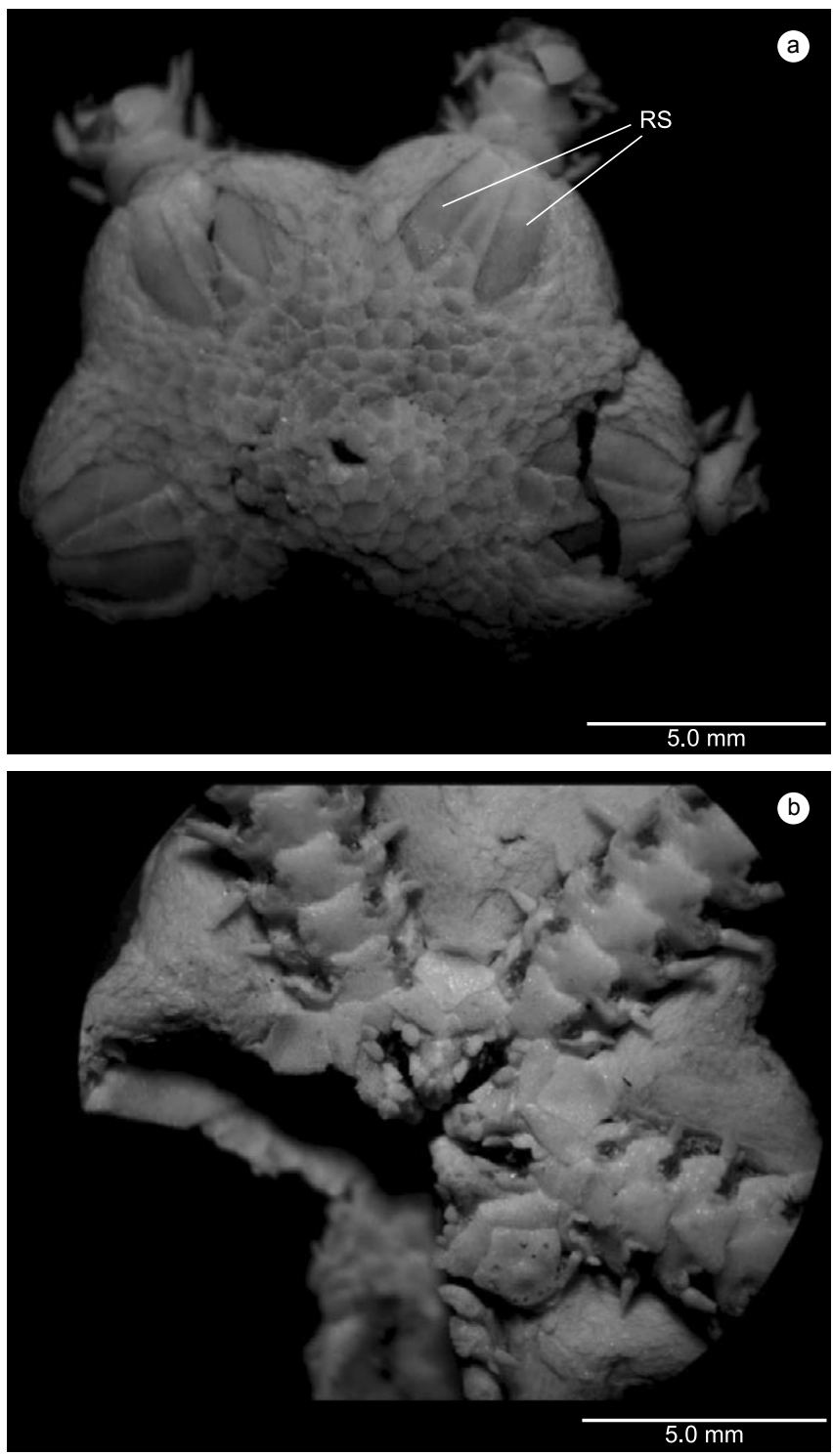

Figure 13. Amphioplus magellanica (Mortensen). a) aboral view: RS- radial shields. and b) oral view. 
Distribution: Chilean Margin ( $31^{\circ}$ to $\left.39^{\circ} \mathrm{S}\right)$ with bathymetric distribution around $300 \mathrm{~m}$.

Suborder Ophiolepidina Ljungman, 1867

Family Ophiolepididae Ljungman, 1867

Ophiomusium biporicum Castillo-Alárcon, 1968 (Figure 14a, b)

Material examined: Sta. \# 7178, 507 m, EqMN 2994

(3 specimens); UFSITAB-85 (2 specimens)

Distribution: Chilean margin $\left(20^{\circ} 15^{\prime} \mathrm{S}\right.$ and $\left.70^{\circ} 18^{\circ} \mathrm{W}\right)$, bathymetric distribution around $582 \mathrm{~m}$.

Ophiomusium lymani Wyville-Thomson, 1873 (Figure 15a, b)

Material examined: Sta. \# 7106, 1,312 m, EqMN 3006 (8 specimens); Sta. \# 7174, 1,153 m, EqMN 3005 (6 specimens), UFSITAB-91 (4 specimens); Sta. \# 7177, 995 m, EqMN 2997 (1 specimen).

Distribution: This species is found in the Pacific, Indian and Atlantic Oceans, with a bathymetric range of $651-4,829 \mathrm{~m}$.
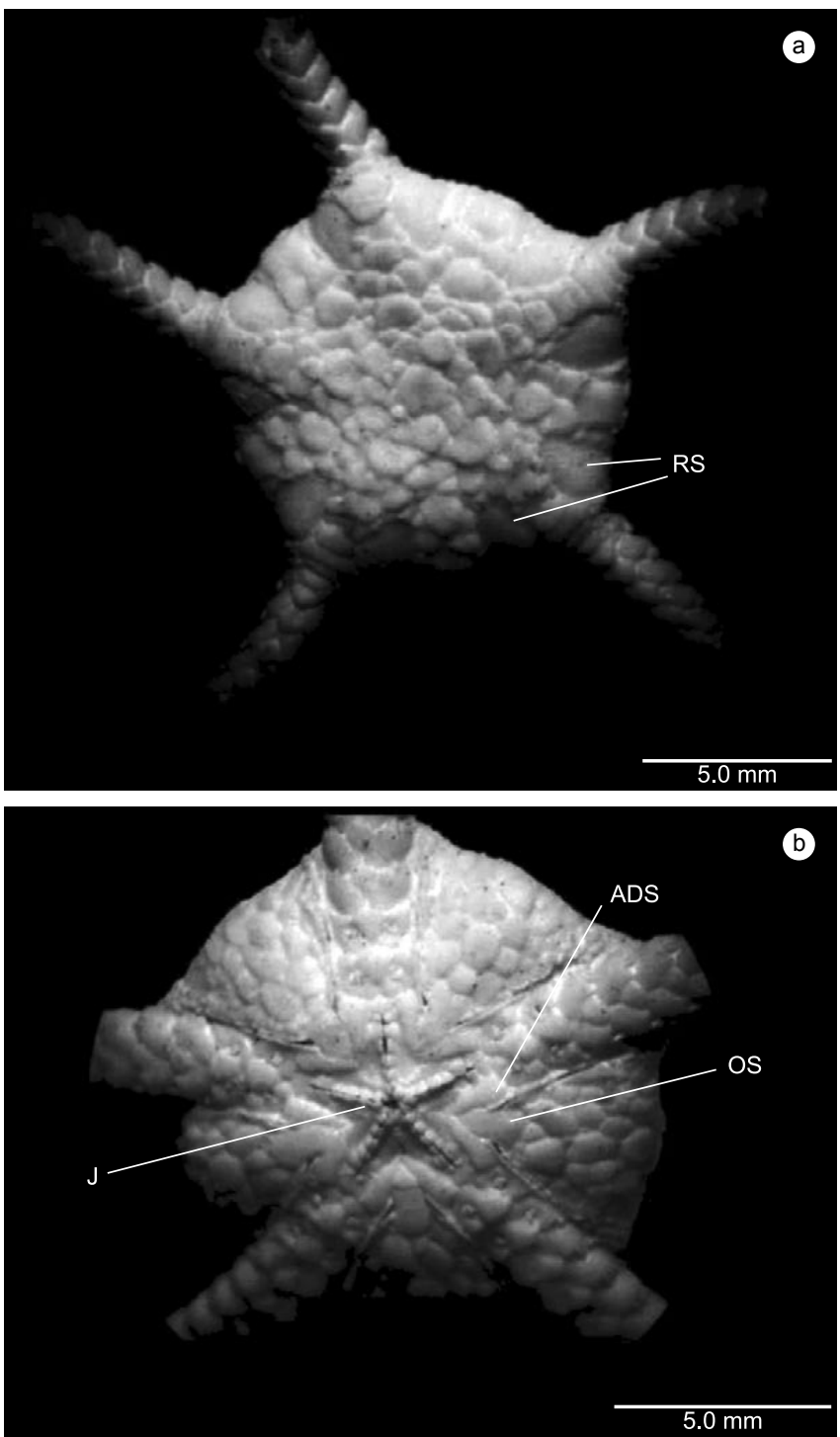

Figure 14. Ophiomusium biporicum Castillo-Alárcon. a) adoral view: RS- radial shields; and b) oral view: OS- oral shield; ADS - adoral shield; J- jaw.

\section{Discussion}

Castillo-Alarcón (1968), with base on the ophiuroid fauna, divided the Chilean margin into three biogeographical zones: 1) from the extreme northern Chile to Talcahuano (i.e., central Chile), including the Juan Fernández Archipelago $\left(20^{\circ} \mathrm{S}\right.$ to $\left.36^{\circ} \mathrm{S}\right)$ occupied by warm-temperate water species; 2 ) between Talcahuano and Valdivia $\left(36^{\circ} \mathrm{S}\right.$ to $39^{\circ} \mathrm{S}$ ), (i.e., central-South Chile). a transition zone with cold-temperate and warm-temperate water species; 3 ) from Valdivia (central-South Chile) to the South, end of Chile with coldtemperate species. The species collected by Expedition "PUCK" can be distributed as follows:

1) First zone: Asteronyx loveni, Ophiolimna bairdi, Ophiocten amitinum, Ophiura (Ophiuroglypha) arntzi sp. nov., Amphioplus magellanica and Ophiomusium lymani; 2) Transition zone: Asteronyx loveni, Ophiocten amitinum and Amphiophiura gallardoi sp. nov; 3) Third zone: Gorgonocephalus chilensis, Astrotoma agassizii, Astrodia tenuispina, Ophiomyxa vivipara, Ophiacantha sp. Stegophiura wilhelmi sp. nov., Ophiura (Ophiuroglypha) lymani, Ophiomusium biporicum, and Ophiomusium lymani.
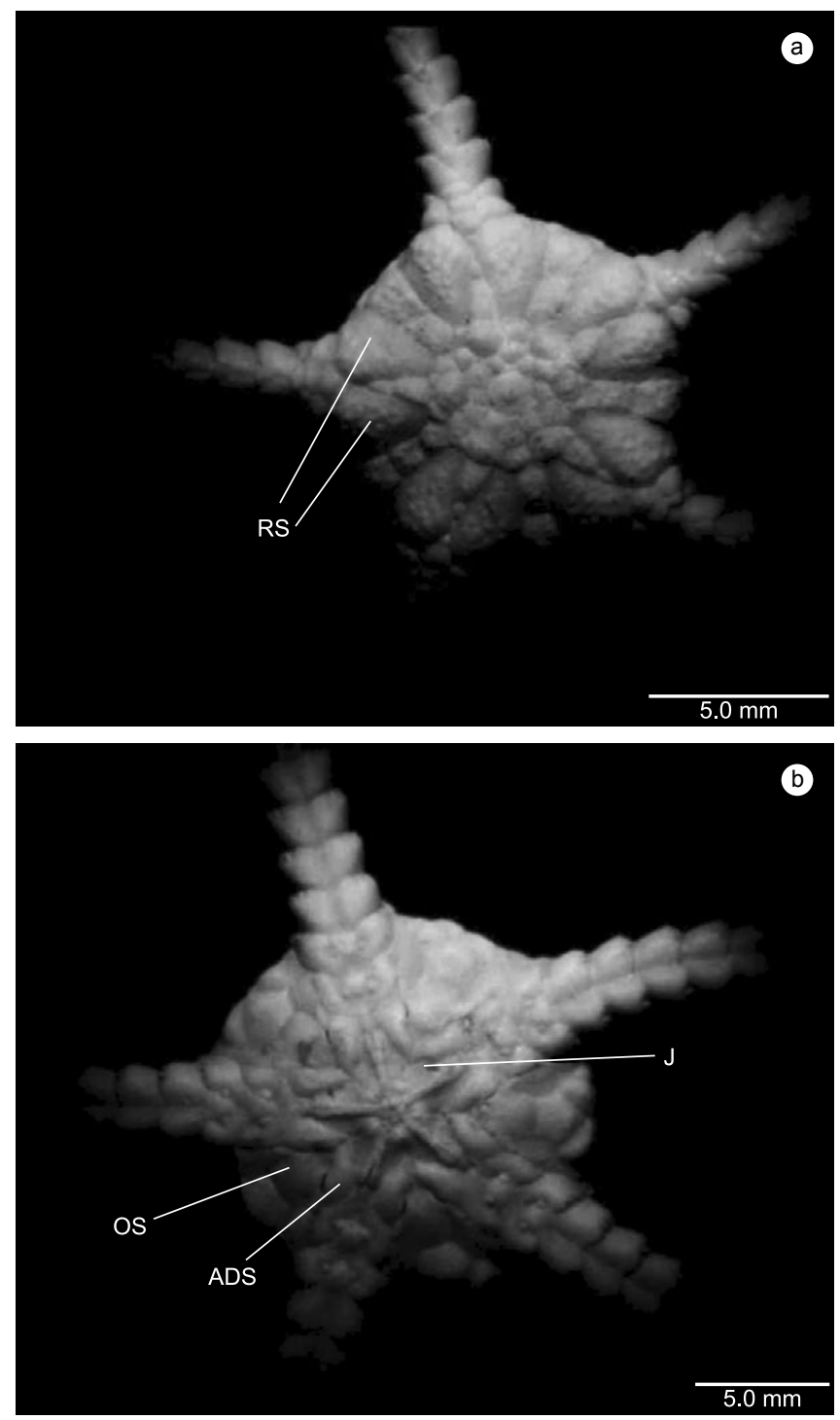

Figure 15. Ophiomusium lymani Wyville-Thomson. a) vista aboral: RS-radial shields. and b) oral view: OS- oral shield; ADS - adoral shield; J- jaw. 
Some authors have tried to understand the circumpolar distribution of some echinoderm species and the faunal relationship between the sub-Antarctic islands, Southern South America, Southern Africa, New Zealand and the Antarctic regions based on a possible submarine topographic connection that could have been available between the end of the Cretaceous or the beginning of the Tertiary (Jaramillo, 1981). Fell (1962) suggested that one of the topographic connections for the echinoderm fauna from the Southern Hemisphere (Antarctic and sub-Antarctic regions) could have been provided by a string of islands separated by narrow channels, uniting the Antarctic, Chile, Argentina, Malvinas Islands, the Scotia Arch and the western Antarctic archipelagos. According to Jaramillo (1981), these topographic links could explain the clear faunal relationships between the archipelagos of the Chiloé and the Los Chonos islands (Southern Chile) with southern Argentina, Malvinas Is., the South Georgia's and the Antarctic.

\section{Acknowledgements}

I am grateful to Dr. Sabine Stöhr of the Stockholm Museum of Natural History, for her kind help with literature and valuable indications on the identification of some species, manuscript revision and valuable suggestions. I would like to thank Dr Vítor A. Gallardo director of the Center of Oceanographic Investigation on the Easter South Pacific at Marine Biology Station of the Concepción University, Chile, for facilities in Chile, and the valuable suggestions for the manuscript. Thanks to Dr. Eduardo Quiroga, from the Center for Research in Patagonian Ecosystems (CIEP), Coyhaique, Chile, for the collection and sorting of the material, and Dr. Dirk Hebbeln, of Geomar, Bremen University, Bremen, Germany, Chief Scientist of the PUCK Expedition. This is a contribution of the CONICYT-Chile, FONDAP-Humboldt and FONDAP-COPAS grants to the University of Concepción, Chile.

\section{References}

ARNTZ, W.E., GORNY, M., SOTO, R., LARDIES, M.A., RETAMAL, M.A \& WEHRTMANN, I.S. 1999. Species composition and distribution of decapod crustaceans in the waters off Patagonia and Tierra del Fuego, South America. Sci. Mar. 63(1):303-31.

BERNASCONI, I. \& D'AGOSTINO, M.M. 1977. Ofiuroídeos del mar epicontinental argentino. Rev. Mus. Arg. Cs. Nat. Hidrobiologia 5(5):65-114.

BRANCH, M.L., JANGOUX, M., ALVÁ, V., MASSIN, C.I. \& SAMPANATO, S. 1993. The Echinodermata of subantarctic Marion and Price Edwards Islands. S. Afr. J.Antarct. Res. 23(1):37-70.

CASTILLO-ALÁCON, J.G. 1968. Contribución al conocimiento de los ofiuroídeos chilenos. Gayana Zool. 14:3-63.
DAHM, C. 1999. Ophiuroids (Echinodermata) of southern Chile and the Antarctic: Taxonomy, biomass, diet and growth of dominant species. In Magellan-Antarctic: Ecosystems That drifted apart (W.E. Arntz \& C. Ríos, eds.). Sci. Mar. 63(Supl. 1):427-432.

DJAKONOV, A.M. 1954. Ophiuroids of the USSR. Moscow, 136p. (Translated from Russian by Israel Program for Scientific Translations, Jerusalem, 1967, 123p.)

FELL, H.B. 1962. A revision of the major genera of amphiurid Ophiuroidea. Trans. Roy. Soc. N. Z. Zool. 2:1-26.

JARAMILLO, E. 1981. Ofiuroídeos de los archipiélagos de Chiloé y los Chonos. S. Neotr. F. Env. 16:113-136.

LUDWIG, H. 1898. Die Ophiuren der Sammlung Plate. Zool. Jahrb. Suppl. 4:750-786.

LUDWIG, H. 1899. Ophiuroideen. (Ergebnisse der Hamburger Magalhaensischen Sammelreise 1892-1893. I Band).

LYMAN, T. 1878. Ophiuridae and Astrophytidae of the H.M.S. Challenger Expedition. Part I. Bull. Mus. comp. Zool. Harv. 5(7):65-168.

LYMAN, T. 1882. Report on the Ophiuroidea dredged by H. M. S. Challenger, during the years 1873-1876. Rep. scient. Res. Voy. Challenger. Zool. 5:1-387.

MORTENSEN, T. 1936. Echinoidea and Ophiuroidea. Discovery Rep. 12:200-348.

MORTENSEN, T. 1952. Echinoidea and Ophiuroidea. Report of the Lund University Chile Expedition 1948-49. Acta Univ. Lund. N. F. 47(8):1-22.

O‘HARA, T.D. \& STÖHR, S. 2006. Deep water Ophiuroidea (Echinodermata) of New Caledonia: Ophiacanthidae and Hemieuryalidae. Tropical Deep Sea Benthos. Memoir. Mus. Natl Hist. 193(24):33-141.

PATERSON, G.L.J. 1985. The deep-sea Ophiuroidea of the North Atlantic Ocean. Bull. Br. Mus. (nat. Hist.) Zool. 49(1):1-162.

QUIROGA, E. \& SELLANES, J. 2009. Growth and size-structure of Stegophiura sp. (Echinodermata: Ophiuroidea) on the continental slope off central Chile: a comparison between cold seep and non-seep sites. J. Mar. Biol. Ass. U.K. 89(2):421-428.

SMITH, A.B., PATERSON, G.L.J. \& LAFAY, B. 1995. Ophiuroid phylogeny and higher taxonomy: Morphological, molecular and palaeontological perspectives. Zool. J. Linn. Soc. 114(2):213-243.

STÖHR, S. 2005. Who's who among baby brittle stars (Echinodermata: Ophiuroidea): postmetamorphic development of some North Atlantic forms. Zool. J. Linn. Soc. 143(4):543-576.

TOMMASI, L.R. 1976. Ophiuroidea collected the Peru-Chile trench by the USNS "ELTANIN" during Cruise III. Pap. Avulsos Zool. 29(28):281-318. 